\section{A Practical Approach in Glycerol Oxidation for the Development of A Glycerol Fuel Cell}

\section{Abstract}

The research on electrochemical carbon molecule oxidation started in the past years as new electrochemistries were researched for new fuel cells systems and batteries that may line up as backup energy supply and storage systems in off-grid and on-grid microgrids, as modeled by our group at the University of Twente [1-3]. By lining up these two disciplines we hope to support the bridge between new electrochemical systems on one side, (pilot) production with partner companies, prediction, and validation of systems upon implementation in microgrids by our group.

The electrochemical oxidation of glycerol in alkaline aqueous solution has been studied on gold and gold coated metals ( $\mathrm{Zn}-\mathrm{Au}$ and $\mathrm{Cu}-\mathrm{Au}$ ) by voltammetry and EIS (Electrochemical impedance spectroscopy) for possible use in a new fuel cell as an outlet for the excess glycerol that is produced in the biodiesel industry. The observations show that the gold surface may change upon cycling by cyclic voltammetry. Besides, the current density shows non-linear behavior with the square root of the scan rate, implying that the reaction is not totally controlled by diffusion. EIS analysis using the EQUIVCRT software revealed that one out of twenty tested equivalent circuits fitted the data well at potentials of $-0.05 \mathrm{~V}$,$0.15 \mathrm{~V}$ and $-0.25 \mathrm{~V}$ vs. $\mathrm{Ag} / \mathrm{AgCl}$, identifying resistors and a Warburg element in parallel with the double layer capacitance, the elements are possibly related to the presence of double layers associated with hydroxypyrovate and oxalate ions. The results are consistent with the low-frequency error fitting analysis $\left(10^{-4}\right)$, AC Simulink-Matlab fitting responds and the Kronig-Kramers transform test. The tested $\mathrm{Zn}-\mathrm{Au}$ and $\mathrm{Cu}$-Au electrodes show similar voltammetry behavior as the gold electrode, as witnessed by the results of cycle analysis and the scan rate analysis. The discharge chronoamperometry test further shows that the $\mathrm{Zn}$-Au electrode and $\mathrm{Cu}$-Au have higher current densities than the gold electrode at a potential of $-0.25 \mathrm{~V}$ vs. $\mathrm{Ag} / \mathrm{AgCl}\left(5 \mathrm{~mA} \mathrm{~cm}^{-2}, 4.5 \mathrm{~mA} \mathrm{~cm}^{-2}\right.$, and $3 \mathrm{~mA} \mathrm{~cm}{ }^{-2}$ respectively).

Keywords: Microgrids; Voltammetry; Oxidation; Gold; Glycerol; Impedance

\section{Quintero Pulido DF ${ }^{1}$, Ten Kortenaar MV², Hurink JL ${ }^{1}$ and Smit GJM ${ }^{1}$}

1 Electrical Engineering, Mathematics and Computer Science, University of Twente, Enschede, The Netherlands

2 Dr Ten BV, Rondweg 11M/N, 8091 XA Wezep, The Netherlands

Corresponding author: Quintero Pulido

戸 d.f.quinteropulido@utwente.nl

Computer Science, Department of Electrical Engineering, Mathematics and Computer Science, University of Twente, P.O. Box 217, 7500 AE Enschede, The Netherlands.

Tel: 0031621323089

Citation: Pulido DFQ, Kortenaar MVT, Hurink JL, et al. A Practical Approach in Glycerol Oxidation for the Development of A Glycerol Fuel Cell. Trends Green Chem. 2017, 3:1.

Received: June 07, 2017; Accepted: June 27, 2017; Published: July 03, 2017

\section{Introduction}

The growing amount of biodiesel produced worldwide leads to more than two million tons of glycerol entering the market yearly [4]. Glycerol is used in the pharmaceuticals, cosmetics and food industries. However, the current production rate already surpasses the capacities needed by these industries. The countries with high production of biodiesel (e.g. USA, Germany and Colombia) are facing serious challenges with the glycerol overproduction changing the value of glycerol dramatically [5]. This specific situation has led to consistently generated low glycerol prices, making glycerol a bio-waste product in the need for new market alternatives. One alternative to valorise glycerol might come from electrochemical oxidation which may give way to oxygenated materials with higher market value (tartronic acid, dihydroxyacetone, and glycolic acid, among others) [6]. The electrochemical oxidation of glycerol may be performed using a fuel cell. Fuel cells can convert directly a fuel into electricity [7]. One common fuel use in fuel cells is $\mathrm{H}_{2}$ and its production is well known in chemical production plants. However, to store hydrogen is still a challenge due to its high volatility and safety concerns [8], one alternative to the problem is to use a fuel that 
is liquid under ambient conditions. There are different types of fuels that were tested in the past as possible alternative fuels such as, hydrazine, organic compounds, and formic acid [9-11]. Nevertheless, there are technical and commercial necessities that a fuel must comply in order to be used in a fuel cell e.g. availability, transport, safety, and cost. Taking this into account, the quantity of possible fuels is reduced to a few types.

Electrochemical oxidation of glycerol has already been considered in the past, and special attention was given towards the selection of catalyst in alkaline and acid media. The following materials have been reported: Pt [12], Pt-Ru [13], Au, Pd [14,15] and $\mathrm{Ag}[16]$. In the case of gold there are several advantages over other catalyst used for glycerol oxidation, e.g. it has a fast electrocatalytic response, is stable in alkaline media, is more abundant and it has a lower price than palladium or platinum [17]. Although gold has been studied as a catalyst for glycerol oxidation, the mechanism of the reaction is still far from being understood. E.g. in the study of Ureta [18], the mechanism of alcohol oxidation in alkaline media on a gold electrode was investigated and it is suggested that the optimal oxidation for alcohols is at $\mathrm{pH}$ 11. Also, Shi [19] studied the kinetics of low concentration of glycerol in alkaline media using voltammetry on a gold foil. Recently, Qi [20] studied the generation of tartronade during glycerol oxidation in alkaline media, using an AuC coated electrode. From these studies were concluded that glycerol oxidation reaction at gold electrode begins with two primary $-\mathrm{OH}$ groups and the chemical reaction possibly decrease the overoxidation of the secondary $-\mathrm{OH}$ and $\mathrm{C}-\mathrm{C}$ bond cleavage. Also, Chornaja [21] proved that the glycerol oxidation pathways are probably two depending on the studied catalyst, leading to the formation of intermediate compounds such as tartronic, lactic, glycolic and oxalic ions. Marshall [22], studied the influence of gold nanoparticles loading on $\mathrm{Au} / \mathrm{C}$ electrode towards glycerol oxidation showing that the oxidation process is dependent on particle load and size distribution. Kwon $[23,24]$ studied the mechanism of glycerol oxidation on polycrystalline gold and platinum electrodes, Kwon found that the glycerol oxidation is strongly influenced by $\mathrm{pH}$, a no catalytic activity was observed in acid media. Padayachee [25] used electrochemical impedance spectroscopy (EIS) with an $\mathrm{Au} / \mathrm{MnO}_{2} /$ Carbon alloy electrode to compare resistances at different potentials. In his study was determined that the lowest cell resistance is at values of $0 \mathrm{~V}$ to $0.2 \mathrm{~V}$ vs. $\mathrm{Ag} / \mathrm{AgCl}$ implying an optimal potential for glycerol oxidation. However, no clear conclusion was drawn for the circuit fitted for the reaction.

In order to build a glycerol oxidation technology viable like in a fuel cell, the mechanism of the chemical reaction has to be studied in more detail to understand the reaction pathways and the kinetics. Also, to make this approach feasible, still more studies need to be done towards development and research of stable electrodes with low catalyst load.

This research aims to yield to an approach for a possible development of a glycerol fuel cell by observing the glycerol oxidation mechanism and kinetics using a gold electrode in alkaline media. Besides, it aims to compare the electrochemical behavior of gold coated metals prepared in situ ( $\mathrm{Zn}-\mathrm{Au}$ and $\mathrm{Cu}$ $\mathrm{Au}$ ) in order to reduce the gold load used for glycerol oxidation and for practical implementation. The practical implementation is related to the use of the glycerol fuel in microgrids. The simulation of renewable energies (solar panel, wind turbines to name a few) combine with batteries and fuel cell is under simulation in our group in The Netherlands [3], however, the large-scale application goes along with an understanding of the chemical, electrochemical and physical characteristics of the different technologies.

This paper is organized as follows: Experimental methods and the EIS fitting circuit is explained. General approach used in this paper for data interpretation is presented. Experimental results testing the gold electrode is divided in three parts. First, voltammetry is used for comparison of catalyst for glycerol oxidation ( $\mathrm{Pt}, \mathrm{Ag}, \mathrm{Au}$, $\mathrm{Cu}$ and glassy carbon). Second, the cyclic voltammetry analysis of cycles and scan rate effect of glycerol oxidation in alkaline aqueous solution on gold electrode is shown. And third, the EIS results for the study of the mechanism that the glycerol oxidation reaction undertakes when using the gold electrode. Practical test with the gold coated $\mathrm{Zn}$ and $\mathrm{Cu}$ electrodes analyzed with cyclic voltammetry and chronoamperometry (cycles and scan rate effect) to observe the glycerol oxidation in alkaline media in comparison with the gold electrode. Lastly, the conclusions are presented.

\section{Experimental Methods}

The reagents: Glycerol $\left(\mathrm{C}_{3} \mathrm{H}_{8} \mathrm{O}_{3}\right) \geq 98 \%, \mathrm{H}_{2} \mathrm{SO}_{4}$ ACS reagent, $37 \%$, $\mathrm{AuBr}_{2}$ reagent $\geq 99 \%$ and $\mathrm{NaOH}$ reagent grade $\geq 98 \%$, pellets were purchased from Sigma-Aldrich were used with no further purification.

The equipment: Cyclic voltammetry-chronoamperometry experiments were performed with a PGSTAT 101 compact unit from the company Metrohm Autolab. The $\mathrm{pH}$ and temperature were recorded with a Hanna HI 9811-5 pH meter. Impedance spectroscopy was performed with a Model 600E Series Electrochemical Analyzer from the company $\mathrm{CH}$ instruments.

The EIS analysis: EIS analysis was done with the EIS fitting procedure in which the elements are analyzed with the software method EQUIVCRT developed by Boukamp [26-28]. This method provides information on the kinetics of the reaction and are validated by a linear Kronig-Kramers transform test method developed by the same author [29]. In this paper, a circuit fitting test in Simulink-Matlab for a view of AC signal output is used, in order to validate the circuit fitted.

The Electrochemical set up: A three electrode ensemble was used for this study. Various working electrodes were used: Glassy carbon (GC), Au, Ag and Pt (Autolab electrodes) and metals such as $\mathrm{Zn}, \mathrm{Cu}$ and carbon graphite (CG) $98 \%$ grade materials from Sigma-Aldrich. The counter electrode was carbon graphite and the reference electrode $\mathrm{Ag} / \mathrm{AgCl}$. The electrode ensemble was immersed in a $50 \mathrm{ml}$ aqueous electrolyte.

Electrochemical coating: Glassy carbon, $\mathrm{Zn}$, and $\mathrm{Cu}$ (area 0.072 $\mathrm{cm}^{2}$ ) were immersed first in a solution of $1 \mathrm{M} \mathrm{H}_{2} \mathrm{SO}_{4}$ for a few seconds to remove impurities, then rinsed with demi-water and dried for an hour. Each of the electrodes was immersed separately in an electrochemical cell with $0.01 \mathrm{M} \mathrm{AuBr}_{2}$ as the 
electrolyte. $\mathrm{AuBr}_{2}$ was selected for electroplating as the subproducts of the electrodeposition are more environmentally friendly than common gold cyanate electrodeposition [30]. The cathode material used was carbon graphite and no reference electrode was used. Then, a potential of $2.0 \mathrm{~V}$ was fixed (letting the current free) in the cell for $30 \mathrm{~s}$ in order to develop a layer of gold as witnessed by a change in color on the electrode. During the experiment, any smell of bromine was not detected. After the electrode plating method, the electrodes were rinsed with demi-water and dried during the night.

\section{General Approach}

An ideal fuel cell system may be interpreted by means of cyclic voltammetry, taking anode and cathode reactions separated. If the two reactions are combined in one plot they may be depicted as shown in Figure 1. In a good glycerol fuel cell, glycerol is oxidized at the anode, and the current density, therefore, should start to rise at a potential as negative as possible. The value of this potential is generally determined by the catalyst, side reactions, and cell resistance. Meanwhile, at the cathode oxygen is reduced and the current density should start to increase at a potential as positive as possible. The max potential of the system is provided by the difference in the glycerol oxidation and oxygen reduction potentials and the current by the steady state rates of these reactions at the anode and at the cathode respectively. This is possible by taking into account the lowest possible ohmic resistance, which is determined by cell geometry, impurities and reaction kinetics. This research is nevertheless focused on analyzing gold as an anode electrode for glycerol oxidation and its possible use in a fuel cell. As literature showed that gold is a relative good electrode, is less corrosive and stable at different $\mathrm{pH}$. Consequently, we looked for the lowest ohmic resistances and low cost substrates for gold coating.

\section{Results and Discussion}

\section{Analysis of catalyst for glycerol oxidation}

In order to gain insight into the glycerol oxidation, cyclic voltammetry is used on the different catalyst as shown in Figure 2. The goal was to get a quick comparison of the electrochemistry

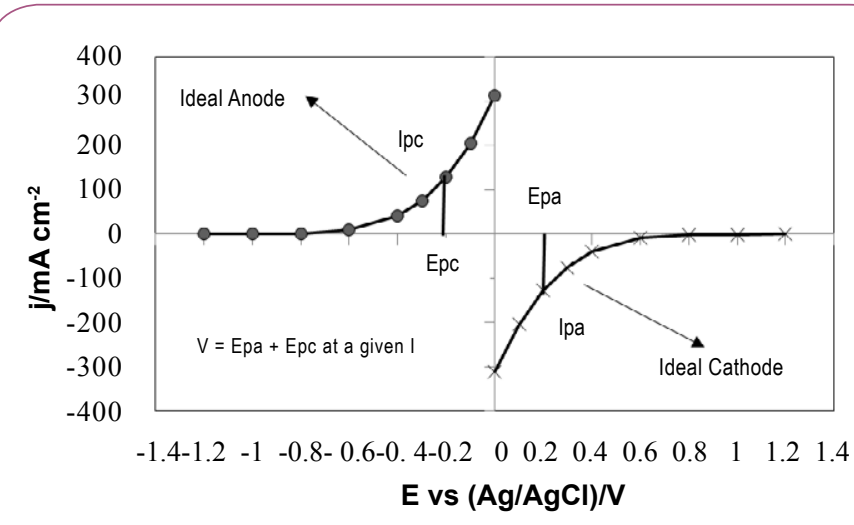

Figure 1 Illustration of an ideal cyclic voltammetry of a fuel cell system with reactions occurring at the cathode and anode electrode. of different catalyst in the same electrolyte. The measurements were done at $100 \mathrm{mV} / \mathrm{s}$ in $1 \mathrm{M}$ glycerol in $1 \mathrm{M} \mathrm{NaOH}$.

The voltammogram for the catalytic effect of Pt for glycerol oxidation in alkaline media in the potential window of $-0.6 \mathrm{~V}$ to $1 \mathrm{~V}$ vs. $\mathrm{Ag} / \mathrm{AgCl}$ is shown in Figure $2 \mathrm{a}$. The first peak $(-0.3 \mathrm{~V}$ and $10 \mathrm{~mA} \mathrm{~cm}^{-2}$ ) corresponds to Pt reduction and the second peak corresponds to glycerol oxidation (around $0.1 \mathrm{~V}$ and $5 \mathrm{~mA} \mathrm{~cm} \mathrm{~cm}^{-2}$ ) in accordance with research reported by Akinbayowa [13]. Figure $\mathbf{2 b}$ and $\mathbf{2 c}$ show the voltammetry of a silver and glassy carbon electrode for glycerol oxidation in alkaline media respectively. Clearly, silver and a glassy carbon have less catalytic effect for glycerol oxidation which is in-line with research performed by Song [31]. The voltammetry for the copper show three current density peaks at different potentials at $-0.3 \mathrm{~V},-0.1 \mathrm{~V}$ and $0.1 \mathrm{~V}$ vs $\mathrm{Ag} / \mathrm{AgCl}$ (Figure 2d). The first two current density peaks (from left to right) might correspond to copper oxidation in different states $\left(\mathrm{Cu}^{3+}\right.$ to $\mathrm{Cu}$ and $\mathrm{Cu}^{2+}$ to $\left.\mathrm{Cu}\right)$ as studied by Rozali [32]. The third peak may be interpreted as a glycerol oxidation. However, it may also be related to corrosion as explained in literature [33]. The glycerol oxidation in alkaline aqueous solution on gold is shown in Figure $2 \mathbf{e}$, where two current density peaks at $-0.2 \mathrm{~V}$ and $-0.1 \mathrm{~V}$ potential are observed. The first peak corresponds to a typical sudden increase in oxidation upon reducing gold from its oxidized state in alkaline media.

The second peak corresponds to the glycerol oxidation which is presented in the literature by different authors [14-22]. In general, the catalytic activity for glycerol oxidation is observed with $\mathrm{Pt}, \mathrm{Cu}$, and $\mathrm{Au}$ electrodes. However, for the $\mathrm{Ag}$ and $\mathrm{GC}$ electrodes, no clear evidence of glycerol oxidation is observed, when comparing the current densities of the different metals at a potential of $-0.2 \mathrm{~V}$. The results show that the gold electrode has the highest value $\left.(11 \mathrm{~mA} \mathrm{~cm})^{-2}\right)$ followed by copper $\left(8 \mathrm{~mA} \mathrm{~cm} \mathrm{~cm}^{-2}\right)$ and the platinum electrode has the lowest current density $(4 \mathrm{~mA}$ $\mathrm{cm}^{-2}$ ). Based on these observations, we focused on the catalytic activity of gold and gold coated $\mathrm{Zn}$ and $\mathrm{Cu}$ electrodes for glycerol oxidation, as further reported below.

\section{Au electrode kinetics}

Figure 3a shows repeated voltammetry cycling (30 cycles) in the potential window between $-0.85 \mathrm{~V}$ to $0 \mathrm{~V} \mathrm{vs}$. $\mathrm{Ag} / \mathrm{AgCl}$ at Au electrode in $1 \mathrm{M}$ glycerol $+1 \mathrm{M} \mathrm{NaOH}$. After each cycle, an increase in current density is observed. This increase in current density may be related to changes in the surface of the electrode. The change in the surface was observed before and after the cycling experiment in Figure $\mathbf{3 b}$. Each cycle may have an effect on the electrode surface, which could affect the catalytic area for the oxidation reaction, thus increasing the current density during the experiment. The changes in the current density are related also to losses in the faradic activity. Glycerol oxidation is affected by the increase in the surface area, as the glycerol ions approaching the electrode interact with the surface creating larger spaces. The current started to increase at around -0.25 $\mathrm{V}$ and the steady increase continues until all glycerol near the surface of the electrode has been oxidized.

To understand more about the kinetics of the glycerol oxidation in alkaline media at the gold electrode, the influence of the 

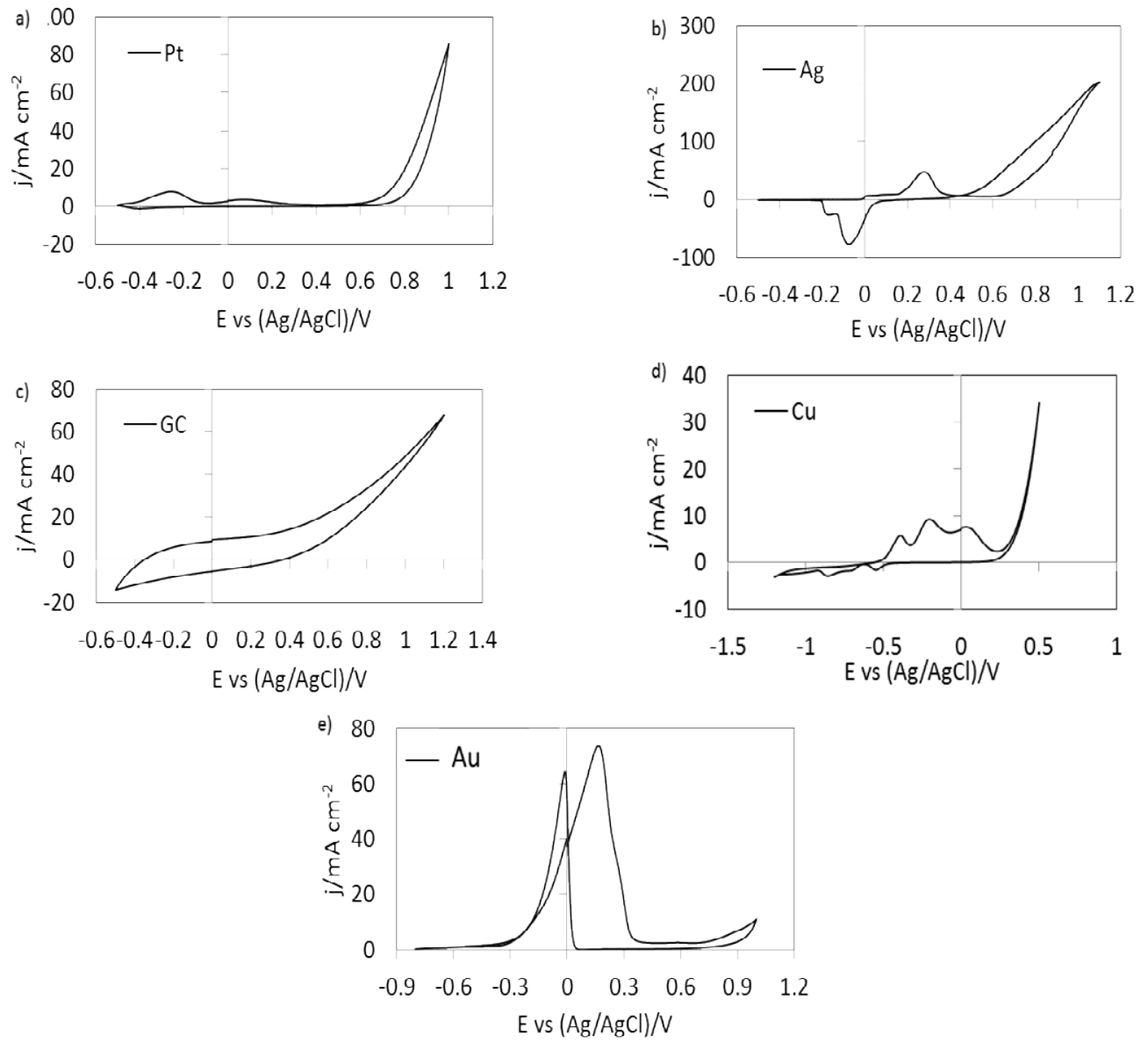

Figure 2 Cyclic voltammetry of a) Pt b) $\mathrm{Ag} \mathrm{c}$ ) GC d) $\mathrm{Cu}$ and e) Au electrode on $1 \mathrm{M} \mathrm{C}_{3} \mathrm{H}_{8} \mathrm{O}_{3}+1$ $\mathrm{M} \mathrm{NaOH}$ electrolyte, $100 \mathrm{mV} / \mathrm{s}$ and $\mathrm{Ag} / \mathrm{AgCl}$ reference electrode.

scan rate is studied in Figure 4a. The current density gradually increased with the scan rates. The correlation between the scan rate and the current density at $-0.15 \mathrm{~V}$ vs $\mathrm{Ag} / \mathrm{AgCl}$ was linear at a scan rate coefficient of $1 / 5\left(I\right.$ vs $\left.v^{1 / 5}\right)$ and not at $1 / 2$ a coefficient (Figure 4b). Other scan rate coefficients were tested (Figure S1) but no linearity was observed. This possibly suggests that the glycerol oxidation on gold electrode is not totally controlled by diffusion and does not follow Levich behavior. Also, with the increase of the scan rate the potential was negatively shifted. The varied potential may represent an alteration in the gold surface due to the interaction with glycerol and $\mathrm{OH}$ ions [34]. However, no clear evidence was observed in the voltammogram for the formation of oxidase compounds. EIS studies could elucidate details about the mechanism of the glycerol oxidation at the gold electrode and find close related oxidized compounds.

\section{Au electrode mechanism for glycerol oxidation in alkaline media and EIS analysis}

EIS analysis was performed in different steps: first, a plausible reaction pathway was taken from literature and a possible reaction model was created. Second, an expected circuit was drawn based on the assumption of the model for the reaction. Third, the circuit was compared with the lab results using the
EQUIVCRT software and fourth the fitted circuits were analyzed with the Kramers-kroning transform and AC Simulink-Matlab circuit signal output to validate the data obtained.

Reaction pathways: Wang [12], explained that glycerol oxidation in an alkaline aqueous solution has two pathways depending on the catalyst. The first reaction path was derived for Pt in which, glyceric acid is the main glycerol oxidation product with tartronic, lactic, glycolic and oxalic acids as by-products (Figure 5a). Glycolic and oxalic acids are formed during the oxidation of tartronic acid. In the same study, it was showed that the reaction products of tartronic acid oxidation with dioxygen in the presence of the $5.7 \%$ $\mathrm{Pt}-2.4 \% \mathrm{Bi} / \mathrm{C}$ catalyst are mesoxalic and oxalic acids. However, the formation of glycolic acid was not detected. For the glycerol oxidation on a $1 \% \mathrm{Au} / \mathrm{C}$ catalyst, the authors found that there is another pathway for the reaction in which glycolate and oxalate ions may be created only by the presence of hydroxypyrovate (with the according to intermediate dihydroxyacetone). One plausible explanation for the two glycerol oxidation paths is the behavior of the glycerol molecule in aqueous solution as shown in literature [35]. It is assumed that glycerol oxidation will take place where the electron goes towards the electrode. In aqueous solution, this happens at the electrode-electrolyte interface. This can be considered as a characteristic of a surface phase, in 


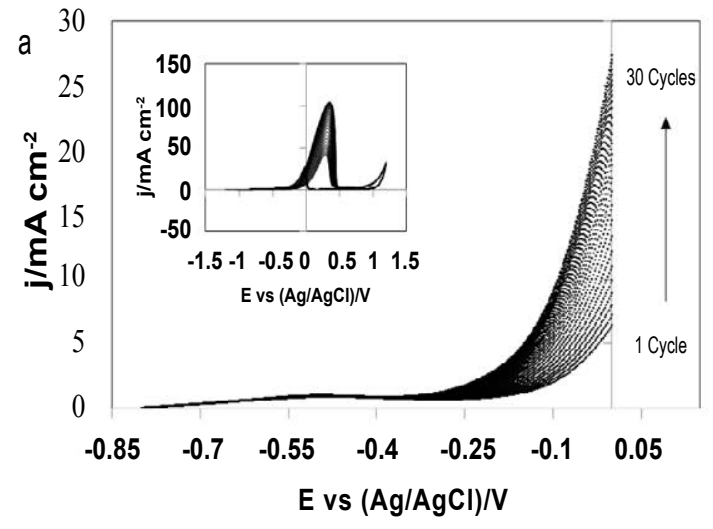

b

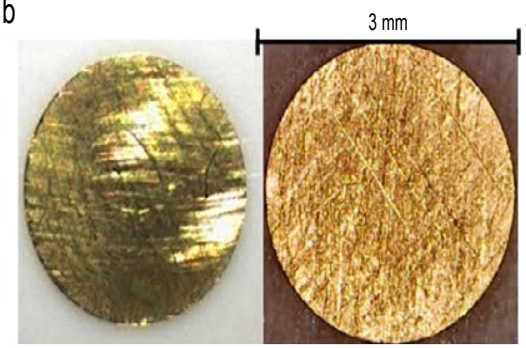

Au electrode Before Au Electrode After

Figure 3 Cyclic voltammetry at an Au electrode on $1 \mathrm{M} \mathrm{C}_{3} \mathrm{H}_{8} \mathrm{O}_{3}+1 \mathrm{M} \mathrm{NaOH}$ electrolyte, $100 \mathrm{mV} / \mathrm{s}$ and $\mathrm{Ag} / \mathrm{AgCl}$ reference electrode a) Glycerol oxidation region between $-0.85 \mathrm{~V}$ and $0 \mathrm{~V}$ showing 30 cycles and b) Au electrode before and after the experiment.
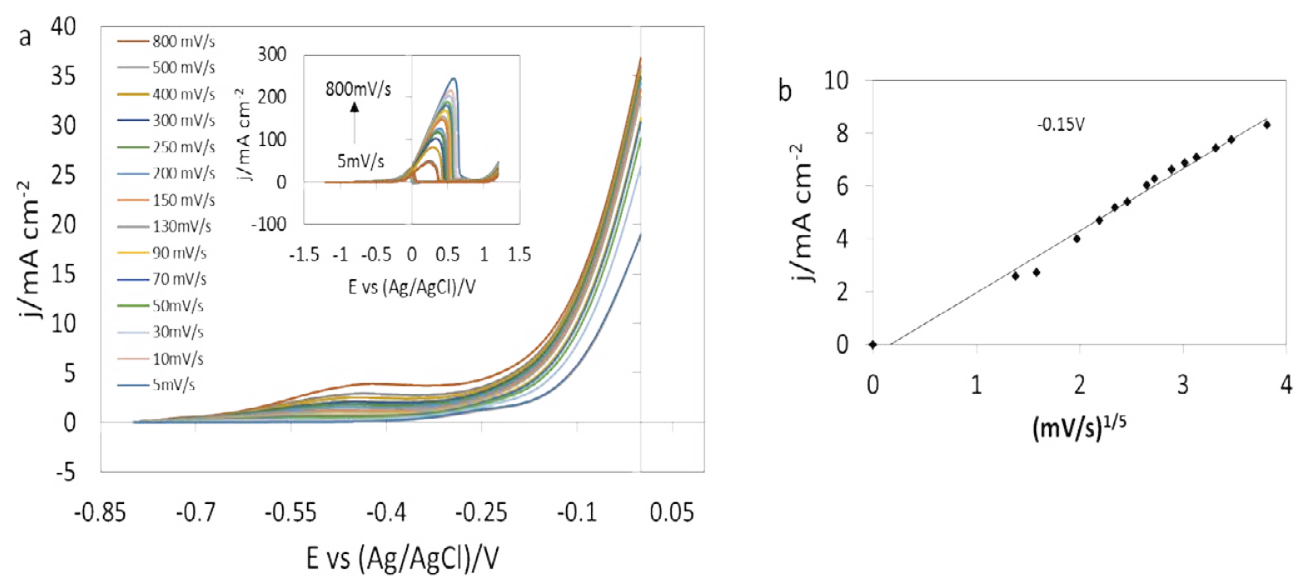

Figure 4 a) Cyclic voltammetry, scan rate effect of an Au electrode spectra between -0.8 and $0 \mathrm{~V} \mathrm{~b}$ ) Current density at $-0.15 \mathrm{~V}$ in relation with the scan rate (I vs. $\left.\mathrm{V}^{1 / 5}\right)$ All experiments used $1 \mathrm{M}$ $\mathrm{C}_{3} \mathrm{H}_{8} \mathrm{O}_{3}+1 \mathrm{M} \mathrm{NaOH}$ electrolyte and $\mathrm{Ag} / \mathrm{AgCl}$ reference electrode.

which there is the existence of an electric field, which is caused by the separation of charges that are in the bulk phases in contact, depending on catalyst the rate of the reaction may be different and this can contribute to the different paths observed with the different catalyst.

\section{Expected circuit}

By using the glycerol oxidation reaction pathway for gold (Figure 5a), an equivalent circuit was derived. Under the assumption that each reaction step maybe represented by a sub-analog electrical element. First, we considered the chemical reaction that is shown in Figure $\mathbf{5 b}$ in which diffusion is followed by physisorption in the outer Helmholtz plane (IHP). Chemisorption processes are presented in parallel to the double layer capacitance in the inner Helmholtz plane (IHP) and various species are captured close to the electrode (oxidation-desorption steps). The concept of a diffusion effect at the beginning of the reaction is related to faradic currents that could occur. This assumption is based on the formation of a thinner Nernst diffusion layer, or with a smaller similar contribution of the absorbed species that are in the overall electrode impedance. The parallel connections in the circuit are associated with the resistances provided by the reactions that occur during physisorption and chemisorption which are related to the oxidation and desorption of ions.

\section{Fitted circuit}

The fitting of the circuit was based on the assumption that one particular circuit may fit (or mimic) all data that was found in the impedance measurements. Figure $6 a$ is the circuit expected for EIS fitting from data in literature. The impedance data was collected at three different potentials $-0.25 \mathrm{~V},-0.15 \mathrm{~V}$ and $-0.05 \mathrm{~V}$ vs $\mathrm{Ag} / \mathrm{AgCl}$ that are in relation with the voltammetry of gold for glycerol oxidation. After testing over 20 circuits in the software EQUIVCRT developed by Boukamp [26], one circuit seemed to fit well the potentials studied for the glycerol oxidation in alkaline media at the gold electrode (Figure 6b). All spectra had an $X^{2}$ value below $10^{-4}$, but although these $X^{2}$ values are large, the circuit mimics reasonably the presented 

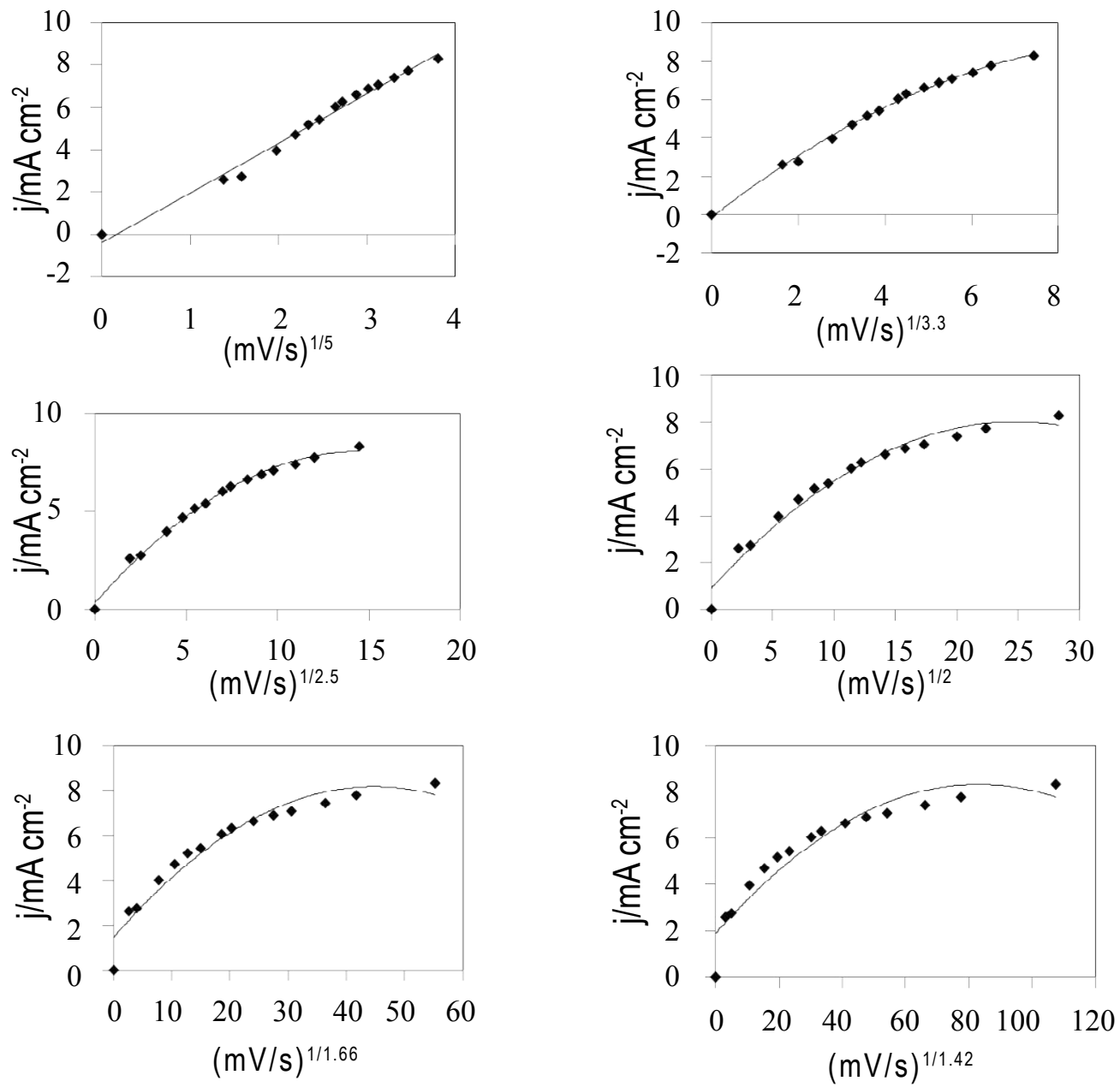

Figure S1 Correlation between current density at $-0.15 \mathrm{~V}$ and a scan rate $\left(\mathrm{v}^{\mathrm{x}}\right)$ with $\mathrm{x}=1 / 5,1 / 3 / 3,1 / 2.5,1 / 2$, $1 / 1.66,1 / 1.42$ on $1 \mathrm{M} \mathrm{C}_{3} \mathrm{H}_{8} \mathrm{O}_{3}+1 \mathrm{M} \mathrm{NaOH}$ electrolyte and $\mathrm{ag} / \mathrm{AgCl}$ reference electrode.
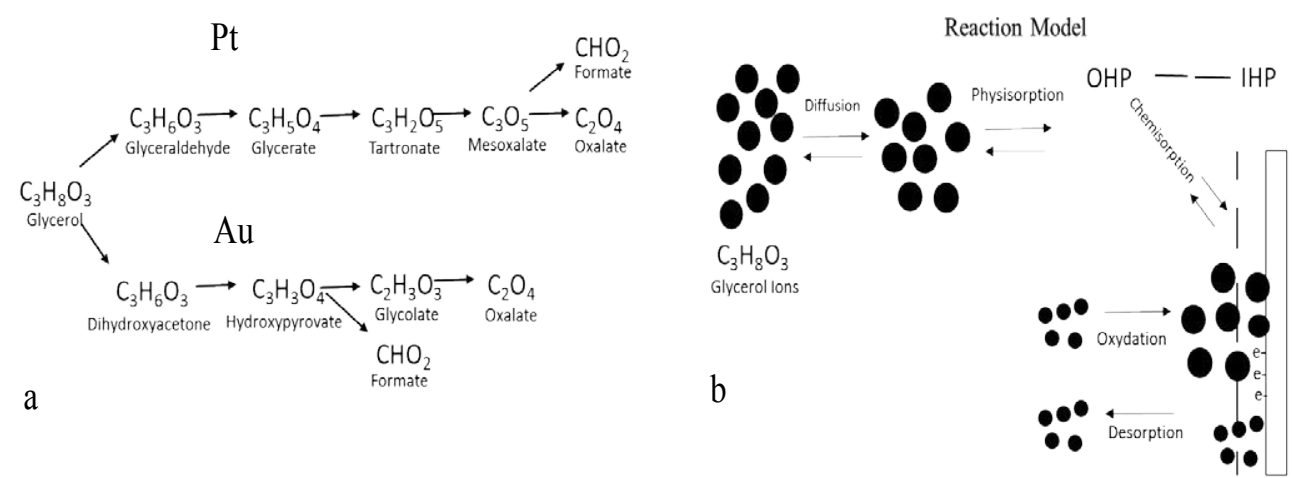

Figure 5 Reaction representation of glycerol oxidation in alkaline media a) Pt and Au catalyst chemical oxidation pathways [12] b) Reaction model for glycerol oxidation in alkaline media on Au electrode, based on data taking from literature. 


\section{Circuit Expected}

a

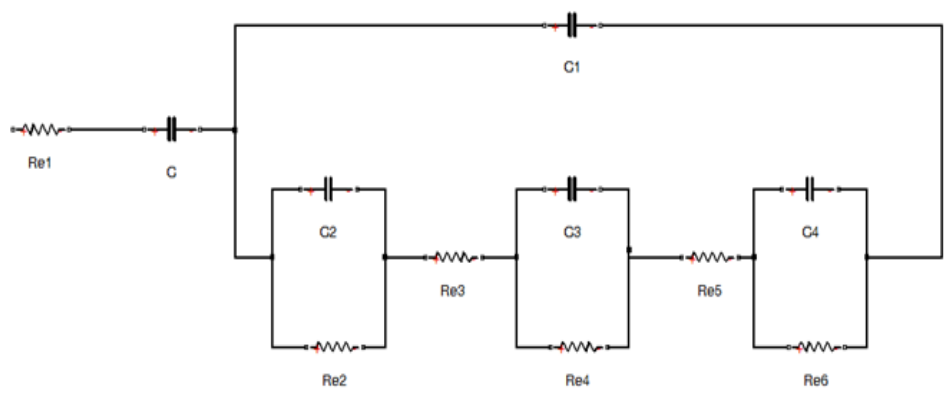

b

Circuit Fitted

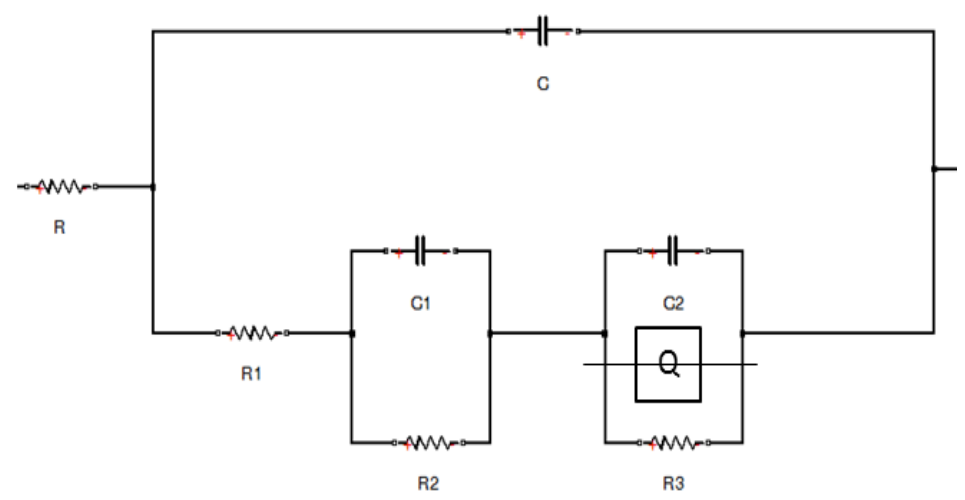

Figure 6 Equivalent circuits for the glycerol oxidation in alkaline media at an Au electrode a) Circuit expected for EIS fitting from data in literature and b) Circuit fitted with EIS software EQUIVCRT.

data and is in line with our comprehension of the reaction, therefore the fitted results were further analyzed. In principal, some of the resistance and the diffusion element are merged, this might be due to the low influence in the frequency studied or do to extreme low noise in the system. A diffusion element (Warburg) is observed in the circuit in parallel with the double layer capacitance, and it is treated as a CPE (constant phase element (Q)) with a value of $n=0.5$ with a capacitor and a resistor in parallel.

\section{Spectra analysis}

The impedance plot at different potentials $(-0.05 \mathrm{~V},-0.15 \mathrm{~V}$ and $-0.25 \mathrm{~V}$ vs $\mathrm{Ag} / \mathrm{AgCl}$ ) was plotted with the real and fitted values, in the voltammetry region for the oxidation of glycerol in alkaline media with the gold electrode are shown in Figure 7a. The lowest resistance is observed in the EIS experiment for the potential of $-0.05 \mathrm{~V}$ vs. $\mathrm{Ag} / \mathrm{AgCl}$ which was also related to the largest current in the reaction voltammogram $\left(30 \mathrm{~mA} \mathrm{~cm}^{-2}\right)$ when compared with the other analyzed potentials.

In order to verify the reliability of the data, the relative residuals are plotted in Figure $\mathbf{7 b}$. The data were obtained by Equation (1):
$\Delta_{\mathrm{re}, i}=\mathrm{X}_{\mathrm{re}, \mathrm{i}}-\mathrm{X}_{\mathrm{re}}(\mathrm{wi}) /|\mathrm{X}(\mathrm{wi})|$ and

$\Delta_{\mathrm{re}, \mathrm{i}}=\mathrm{X}_{\mathrm{im}, \mathrm{i}}-\mathrm{X}_{\mathrm{im}}(\mathrm{wi}) /|\mathrm{X}(\mathrm{wi})|$

Here, $X_{\text {re, }}$ and $X_{i m, i}$ are the real and imaginary parts of the impedance at a data point $(\mathrm{i}), \mathrm{X}_{\mathrm{re}}(\mathrm{wi}), \mathrm{X}_{\mathrm{im}}(\mathrm{wi})$ are the real and imaginary parts of the modeling function for wi. The $\mid X($ wi $) \mid$ is the vector length expressed in the absolute value of the modeling function ( $X$ can also represent the statistical behavior of the correlation for fitted data in the circuit). The residuals show a trend that is closer to values between $0-1 \%$ for the error in the data fitting, showing that data in the fitting correlation had a low error percentage in all the applied potentials.

Table 1 shows the values of the elements collected from the fitted circuit (resistors, capacitors, and $Q$ element), with an increase of the potential the fitted elements change proportionally. The first resistance $(R)$ is the largest resistance due to the distance of the particles that need to travel to the electrode double layer. The first capacitor (C) represents the double layer capacitance, which is approximately the same at all the potentials, together with the resistance in parallel (R1) that is connected to the second set of resistances-capacitor that are in series(R2C1 and $R 3 C 2$ ). In all the cases $Q$ has an $n$ value of closely to 0.5 indicating the presence of the $\mathrm{W}$ element. 

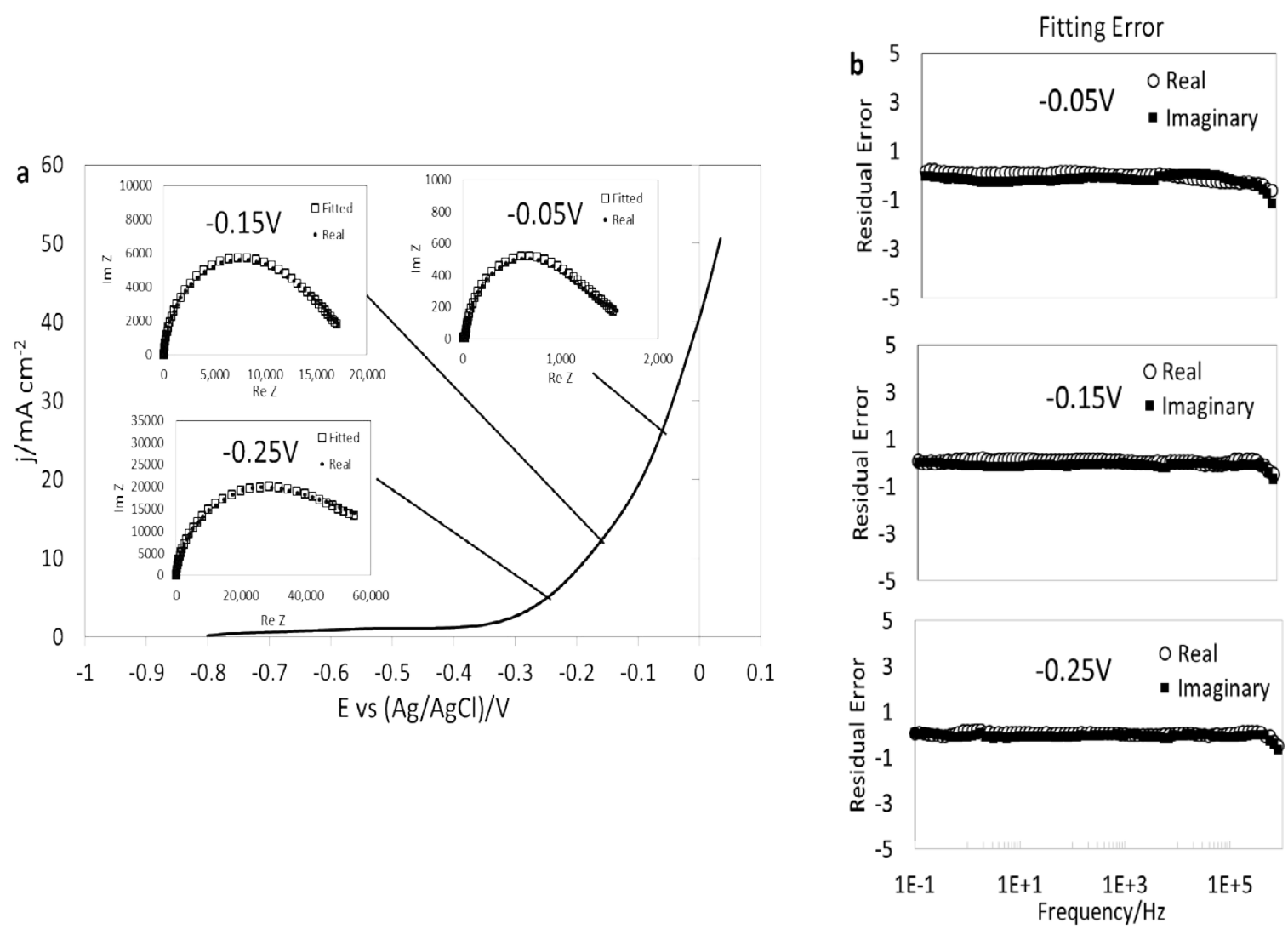

Figure 7 a) Impedance spectra real $\left({ }^{*}\right)$ and fitted data( $\left.\square\right)$ at different negative potentials together with the steady-state current from Au CV experiments on $1 \mathrm{M} \mathrm{C}_{3} \mathrm{H}_{8} \mathrm{O}_{3}+1 \mathrm{M} \mathrm{NaOH}$ electrolyte $100 \mathrm{mV} / \mathrm{s}$ and an $\mathrm{Ag} / \mathrm{AgCl}$ reference electrode. b) fitted $(*)$ and real ( $\square$ ) equivalent circuit frequency error.

Table 1 Values obtained for the circuit fitted for the Impedance spectra of $1 \mathrm{M} \mathrm{C}_{3} \mathrm{H}_{8} \mathrm{O}_{3}+1 \mathrm{M} \mathrm{NaOH}$.

\begin{tabular}{|c|c|c|c|c|c|c|c|c|c|c|}
\hline$v(V)$ & $R(\Omega)$ & $C(F)$ & $\mathbf{R} 1(\Omega)$ & $\mathbf{R} 2(\Omega)$ & C1 & $\mathbf{R} 3(\Omega)$ & $\mathbf{Q}(\mathbf{F})$ & $\mathbf{n}$ & C3 (F) & $x^{2}$ \\
\hline-0.05 & $3.81 E+00$ & $6.51 \mathrm{E}-08$ & $1.66 \mathrm{E}+01$ & $4.08 \mathrm{E}+02$ & $3.23 \mathrm{E}-04$ & $1.36 \mathrm{E}+03$ & 5.65E-05 & 4.34E-01 & 2.09E-06 & 4.83E-04 \\
\hline-0.15 & $3.68 \mathrm{E}+00$ & 7.36E-08 & $1.69 \mathrm{E}+01$ & $1.20 \mathrm{E}+02$ & $2.22 \mathrm{E}-04$ & $1.95 \mathrm{E}+04$ & $1.08 \mathrm{E}-05$ & $4.02 \mathrm{E}-01$ & $1.40 \mathrm{E}-06$ & $1.45 \mathrm{E}-04$ \\
\hline-0.25 & $3.54 \mathrm{E}+00$ & 7.97E-08 & $1.61 \mathrm{E}+01$ & $2.14 \mathrm{E}+04$ & $1.62 \mathrm{E}-04$ & $6.05 \mathrm{E}+04$ & 4.74E-06 & 4.78E-01 & $1.31 \mathrm{E}-06$ & 1.17E-04 \\
\hline
\end{tabular}

\section{Data reliability}

In order to validate the circuit modeled. The circuit fitted may be tested using the K-K transform by the method described by Boukamp [29]. Figure 8 shows that the data was transformed according to $\mathrm{K}-\mathrm{K}$ theory thus confirming that the data is reliable. The capacitors and the resistors presented in this studied are based on fitting and their actual presence in the reaction are not ascertained. However, based on the low-frequency spectra it is possible to observe the presence of capacitors. This could imply that the processes are slow. Also, the analysis of the residual error supports the theory of the presence of the capacitive structures in the reaction. Furthermore, in order to validate the data further Simulink-Matlab was used and the Simulink circuit fitting is shown in Figure 9. The fitted circuit is connected in series with regular AC circuit elements available in the Simulink package, the logic of the system is given by the scope unit. The signal from the circuit indicates that the circuit has a logical frequency output, and it may be used as an electronic system.

\section{Gold coated metals proof of concept}

Although the analysis with the gold electrode showed good results for glycerol oxidation in alkaline media, current densities and potentials are still low for a realistic scenario in a fuel cell construction. In order to offer an alternative for the gold electrode, this section presents first, a gold coating method for glassy carbon and the voltammetry test which is compared with gold in alkaline and in acid media to observe the changes in current density and potential in $1 \mathrm{M}$ glycerol aqueous solution. Second, two gold coated metals are tested ( $\mathrm{Zn}-\mathrm{Au}$ and a $\mathrm{Cu}-\mathrm{Au}$ ) in order to compare their electrochemical behavior against pure gold. $\mathrm{Zn}$ or Cu may be subject to corrosion but no corrosion was observed in the current experiments.

Gold Coating effect: Glassy carbon (GC) was used as material to deposit gold with the method described in Experimentak Methods, the GC electrode without gold is shown in Figure 10a. A clear layer of gold was deposited (Figure 10b).The gold deposition corresponds to the classical electrochemical- 

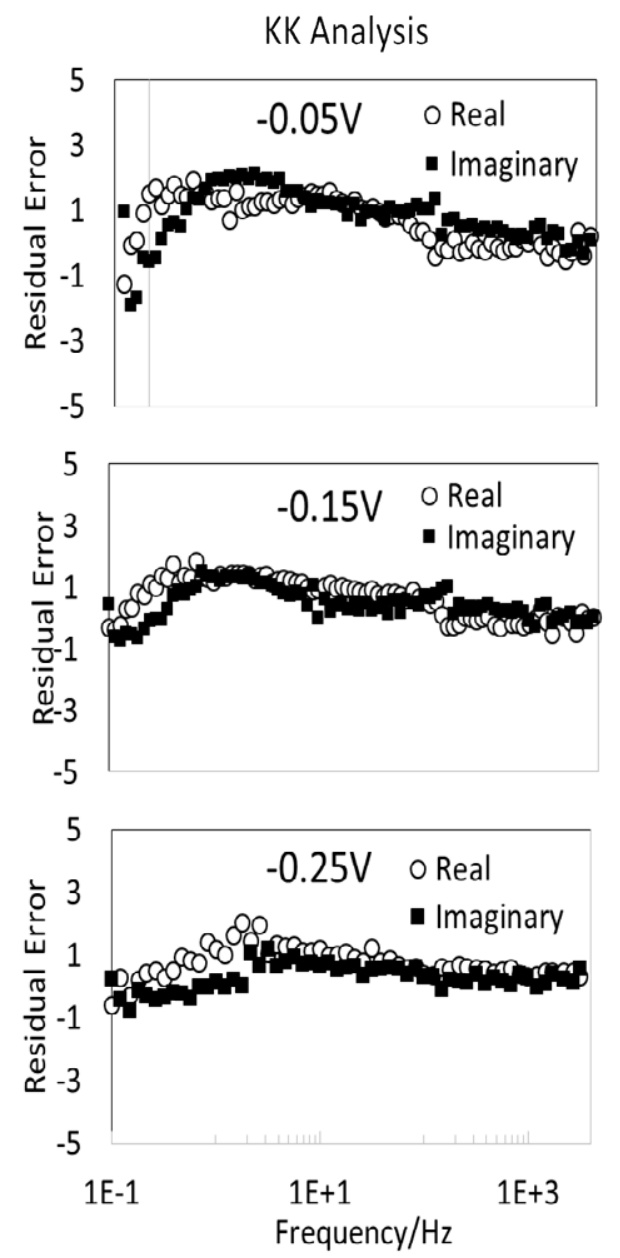

Figure 8 K-K transform analysis for experimental data of impedance measurements of $\mathrm{Au}$ electrode in $1 \mathrm{M} \mathrm{C}_{3} \mathrm{H}_{8} \mathrm{O}_{3}+1 \mathrm{M} \mathrm{NaOH}$ and $\mathrm{Ag} / \mathrm{AgCl}$ reference electrode.

nucleation phenomenon in which the gold ions are traveling through the electrolyte in a diffusion control behaviour [36]. After the electrode was prepared, two cyclic voltammograms were measured one with glycerol in acidic media (Figure 10c) and one with glycerol in alkaline media (Figure 10d). Both voltammograms were compared with the gold electrode.

The CV of GC-Au electrode compared with the gold electrode in acid media is shown in Figure 10c. When the potential increases in the positive direction of the scan a first current density peak was observed, possibly, corresponding to gold oxidation, then the potential changed and the gold reduction current density peak was observed. This behavior is typical for a gold electrode in acid media [17]. In both the GC-Au and the gold electrode, cathodic and anodic current density peaks were observed, this is an indication that gold was present on the GC electrode showing similar behavior than the gold electrode. However, it was not observed a clear evidence of glycerol oxidation during the experiment. Also, the GC-Au showed lower current densities than the gold electrode, the reasons for this are may be related to the size of the gold layer, the GC-Au stability and possibly intrinsic resistances between the materials [37].

Figure $10 \mathrm{~d}$ shows the CV of gold and GC-Au electrodes in $1 \mathrm{M}$ glycerol in $1 \mathrm{M} \mathrm{NaOH}$. It was observed that the GC-Au electrode had a similar behavior than the gold electrode showing two current density peaks, (one for the gold reduction at approximately $0 \mathrm{~V}$ and one for glycerol oxidation at approximately $0.2 \mathrm{~V} v \mathrm{vs} . \mathrm{Ag} /$ $\mathrm{AgCl})$. The comparison showed that similar voltammograms may be achieved by using the gold coating method however, lower current densities were observed when using GC electrode as a substrate for gold deposition in comparison with the gold electrode.

In both acid and alkaline media, the CV behavior of gold electrode was observed when using GC-Au electrode. Furthermore, it is suggested that using GC as a substrate material for gold plating has an effect on the current density, potential, and the capacitive plateau during voltammetry. This effect may be due to the electrochemical nature of GC, which may affect the normal behavior of the gold electrode for glycerol oxidation [18], similar observations were done by Othman [38], in which Au-PVC electrode was used for glycerol oxidation and it was observed that the gold coated material can mimic the electrochemical behavior of gold.

\section{The $\mathrm{Zn}$-Au electrode}

Based on the observations done with the GC electrode. It is plausible that changing the substrate material for gold electrodeposition may affect the current density and potential in the voltammetry of glycerol in alkaline media. A Zn-Au electrode was prepared using the same procedure for the GC-Au electrode. The electrode was checked visually before and after been in the aqueous solution of $\mathrm{AuBr}_{2}$ and it was observed a change in color on the surface of the zinc electrode, the change may be related to zinc oxidation [39] and also, to a displacement of zinc ions for gold ions [40]. In order to observe if gold is presented on the surface of the zinc electrode voltammetry was used. Furthermore, the effect of cyclic voltammetry cycling is presented in Figure 11. Thirty cycles are shown at a scan rate of $100 \mathrm{mV} / \mathrm{s}$, the shape of the voltammetry is similar to the gold electrode implying, that possibly a gold layer was created on the surface of the zinc electrode and that glycerol oxidation may be possibly achieved similarly than with gold. After each cycle in the voltammetry, the current density increased, having a similar effect than the GC-Au electrode. This observation also suggests that the $\mathrm{Zn}$ $\mathrm{Au}$ electrode has a layer of gold deep enough to continue the glycerol oxidation during each cycle.

To understand more about the kinetics of the glycerol oxidation in alkaline media at $\mathrm{Zn}$-Au electrode, the influence of scan rate is studied in Figure 12a. Similar to the GC-Au electrode, the current density gradually increased with the scan rates, and the correlation between the scan rate and the current density at $-0.15 \mathrm{~V}$ is linear at a scan rate coefficient of $1 / 5\left(\mathrm{I} \mathrm{vs} . \mathrm{V}^{1 / 5}\right)$ and not at $1 / 2$ (Figure 12b). Other scan rates exponential coefficients were tested but not linearity was observed. This observation may suggest that the glycerol oxidation using the $\mathrm{Zn}$-Au electrode is not totally controlled by diffusion, as in the case with the GC- 


\section{Simulink circuit fitting}

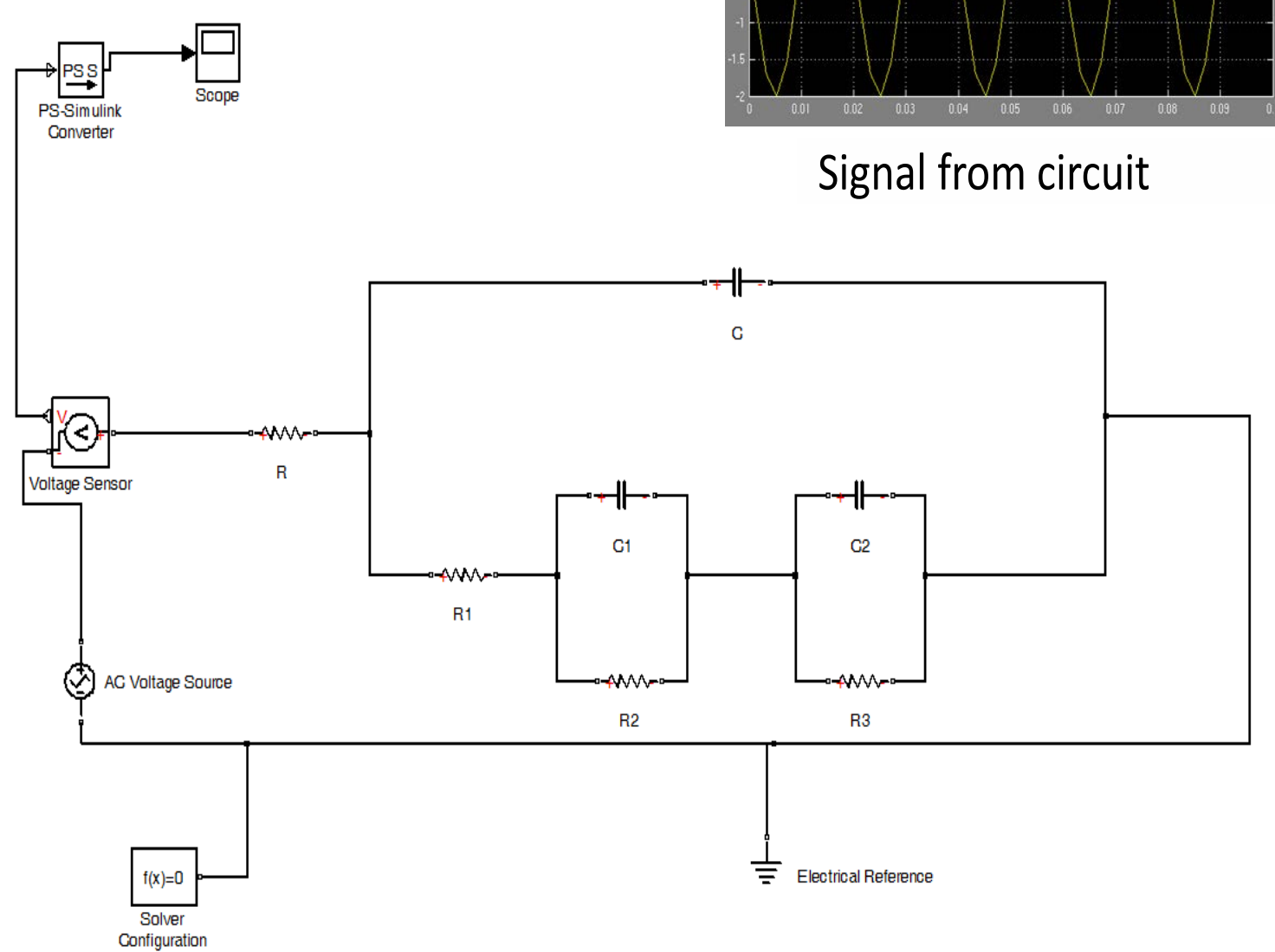

Figure 9 Simulink-Matlab test with AC signal output for circuit fitted for glycerol oxidation in alkaline media on a gold electrode.

Au electrode. Also, with the increase of scan rate the potential is negatively shifted. The varied potential may represent both an alteration in the $\mathrm{Zn}$-Au surface due to the interaction with glycerol and $\mathrm{OH}^{-}$ions [34], and the interaction between gold and zinc that shifted the potential to negative values, this possibly related to the negative electrochemical potential of zinc and possible side reaction of zinc in alkaline media forming zinc oxide and zinc hydroxide both with larger negative potential than zinc as shown in Equation 2. However, the actual presence of these reactions was not characterized in detail in this study.

$\begin{array}{lcc}\text { Reaction } & & \mathrm{E}^{\circ} / \mathrm{V} \\ \mathrm{Au}^{2+}+\mathrm{e}^{-} \square \quad \mathrm{Au} & & +1.8 \\ \mathrm{Zn}^{2+}+2 \mathrm{e}^{-} \square \quad \mathrm{Zn} & & -0.7618 \\ \mathrm{Zn}(\mathrm{OH})_{4}^{2-}+2 \mathrm{e}^{-} \square & \mathrm{Zn}+4 \mathrm{OH}^{-} & -1.199 \\ \mathrm{Zn}(\mathrm{OH})_{2}+2 \mathrm{e}^{-} \square & \mathrm{Zn}+2 \mathrm{OH}^{-} & -1.249 \\ \mathrm{ZnO}+\mathrm{H}_{2} \mathrm{O}+2 \mathrm{e}^{-} \square & \mathrm{Zn}+2 \mathrm{OH}^{-} & -1.260\end{array}$

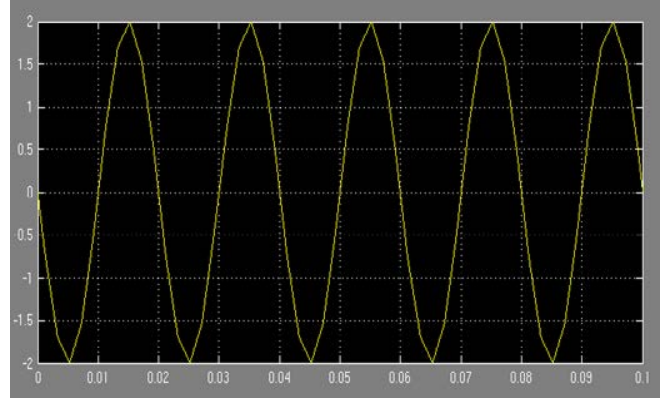

\section{Signal from circuit}

\section{The Cu-Au electrode}

The $\mathrm{Cu}-\mathrm{Au}$ electrode was studied using the same conditions for the GC-Au electrode and the $\mathrm{Zn}$-Au electrode. The electrode was checked visually before and after being in the aqueous solution of $\mathrm{AuBr}_{2}$ the color on the surface of the copper electrode changed. The change may be possibly related to copper oxidation [41]. Also, it may result from displacement of copper ions for the more noble gold ions [40]. The effect of cyclic voltammetry cycling is presented in Figure 13. The shape of the voltammetry is similar to the gold electrode the GC-Au and $\mathrm{Zn}$-Au electrode, showing that a gold layer was created on the surface of the copper and that similar shape can be observed in the voltammetry of glycerol oxidation as compared with the Au electrode. After each cycle in the voltammetry, the current density increased similarly to the GC-Au and the $\mathrm{Zn}$-Au electrodes. This observation also suggests that the $\mathrm{Cu}-\mathrm{Au}$ electrode had enough gold to continue the constant cycling.

The influence of scan rate is shown in Figure 14a. It can be seen that the current density gradually increased with the scan rates. 


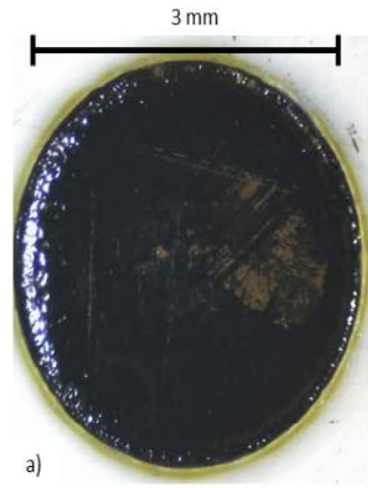

GC without Au Coating

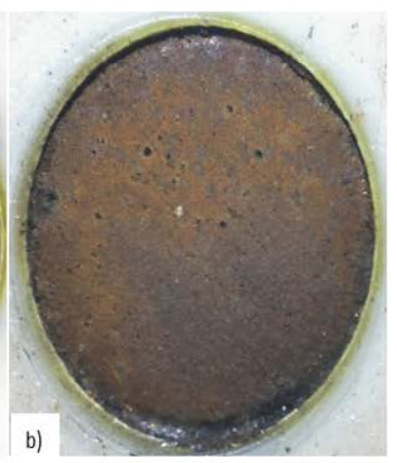

GC with Au Coating
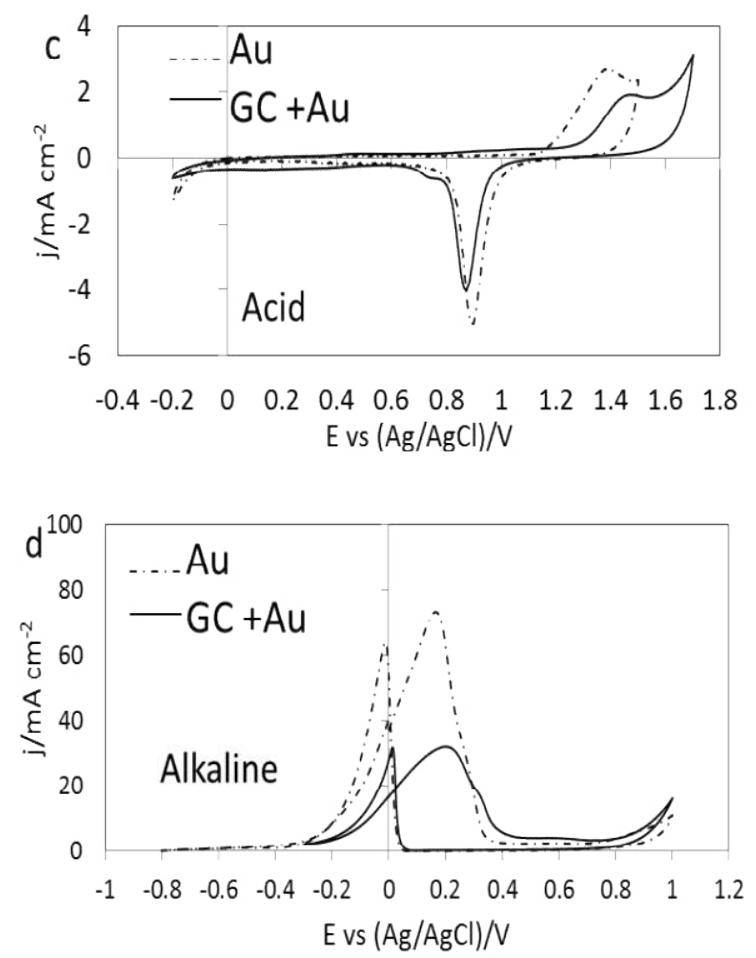

Figure 10 a) GC electrode without Au coating b) GC electrode with Au coating and cyclic voltammetry of gold electrode and GC-Au electrode on c) Acid media $\left(1 \mathrm{M} \mathrm{C}_{3} \mathrm{H}_{8} \mathrm{O}_{3}+1 \mathrm{M} \mathrm{H}_{2} \mathrm{SO}_{4}\right)$ d) Alkaline media $\left(1 \mathrm{M} \mathrm{C}_{3} \mathrm{H}_{8} \mathrm{O}_{3}+1 \mathrm{M} \mathrm{NaOH}\right)$. Both at $100 \mathrm{mV} / \mathrm{s}$ and $\mathrm{Ag} / \mathrm{AgCl}$ reference electrode.

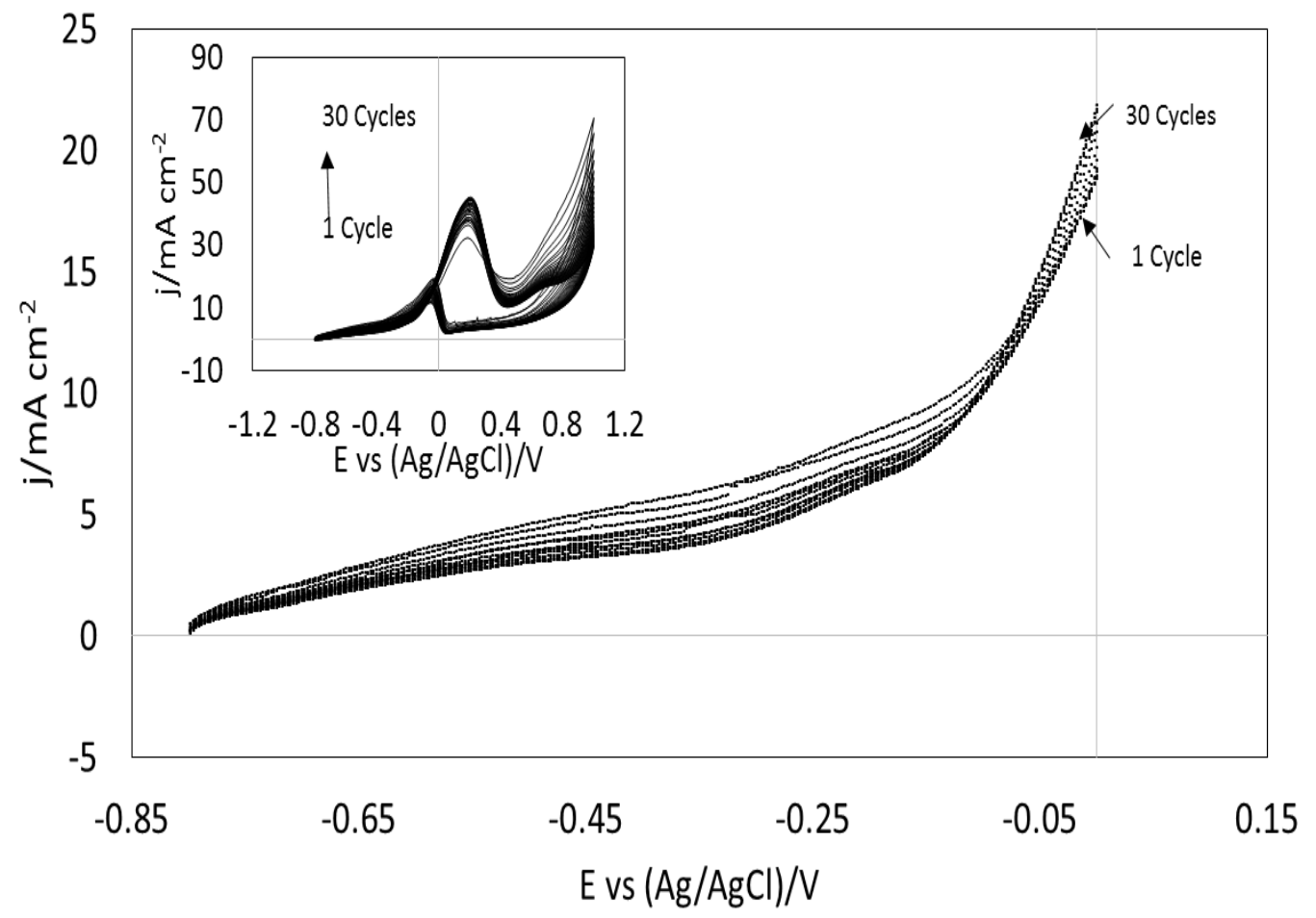

Figure 11 Cyclic voltammetry cycles effect at $\mathrm{Zn}$-Au electrode on $1 \mathrm{M} \mathrm{C}_{3} \mathrm{H}_{8} \mathrm{O}_{3}+1 \mathrm{M} \mathrm{NaOH}$ electrolyte, $100 \mathrm{mV} / \mathrm{s}$ and $\mathrm{Ag} /$ $\mathrm{AgCl}$ reference electrode. 
a

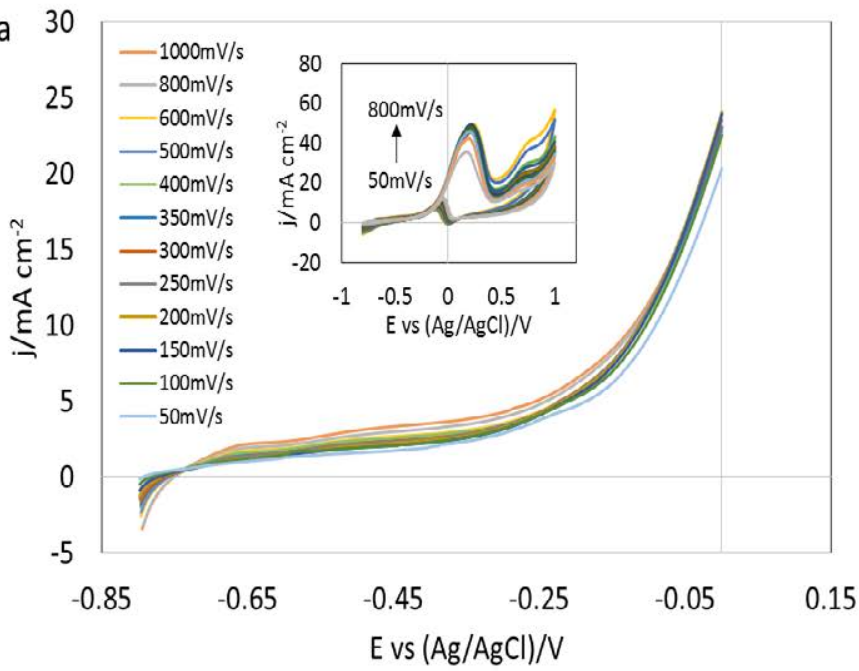

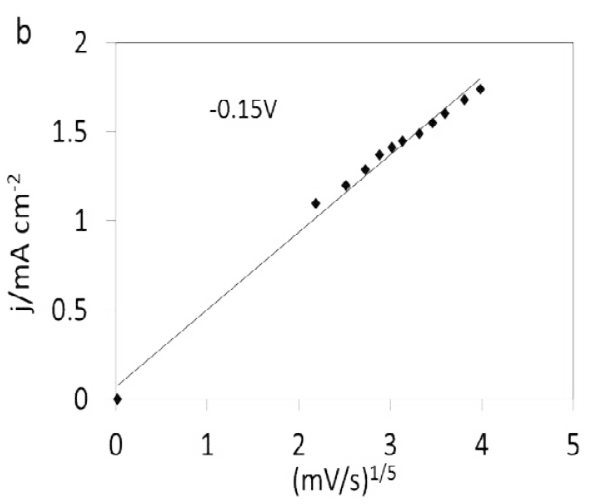

.15

Figure 12 a) Scan rate effect on Cyclic Voltammetry of Zn-Au electrode b) Current density at $-0.15 \mathrm{~V}$ relation with scan rate $\left(\mathrm{Vs} \mathrm{v}^{1 / 5}\right)$, on $1 \mathrm{M} \mathrm{C}_{3} \mathrm{H}_{8} \mathrm{O}_{3}+1 \mathrm{M} \mathrm{NaOH}$ electrolyte and $\mathrm{Ag} / \mathrm{AgCl}$ reference electrode.

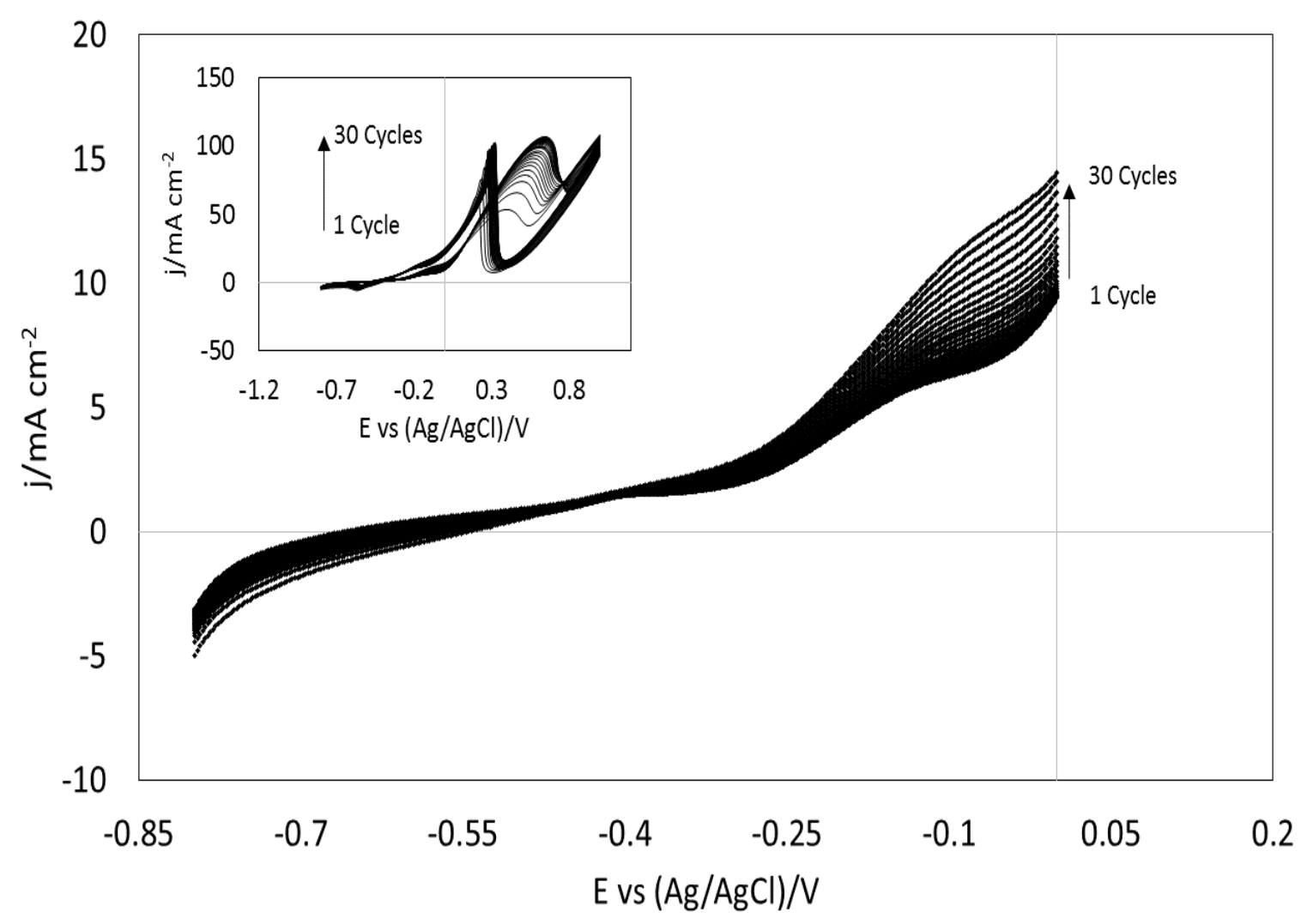

Figure 13

Cyclic voltammetry cycles effect at $\mathrm{Cu}-\mathrm{Au}$ electrode on $1 \mathrm{M} \mathrm{C}_{3} \mathrm{H}_{8} \mathrm{O}_{3}+1 \mathrm{M} \mathrm{NaOH}$ electrolyte, $100 \mathrm{mV} / \mathrm{s}$ and Ag/ $\mathrm{AgCl}$ reference electrode.

The correlation between the scan rate and the current density was measured at a potential of $-0.15 \mathrm{~V}$ vs. $\mathrm{Ag} / \mathrm{AgCl}$ and it was found to be linear at a scan rate coefficient of $1 / 5\left(I \mathrm{vs} . \mathrm{V}^{1 / 5}\right)$ and not at $1 / 2$ (Figure 14b). These observations suggest that the glycerol oxidation at $\mathrm{Cu}-\mathrm{Au}$ electrode is not totally controlled by diffusion. Also, with the increase of scan rate the potential is negatively shifted similarly to the $\mathrm{Zn}$-Au electrode. The varied potential possibly represents both an alteration in the coppergold surface due to the interaction with glycerol and $\mathrm{OH}^{-}$ions produce during the voltammetry [34]. The voltammetry of the 

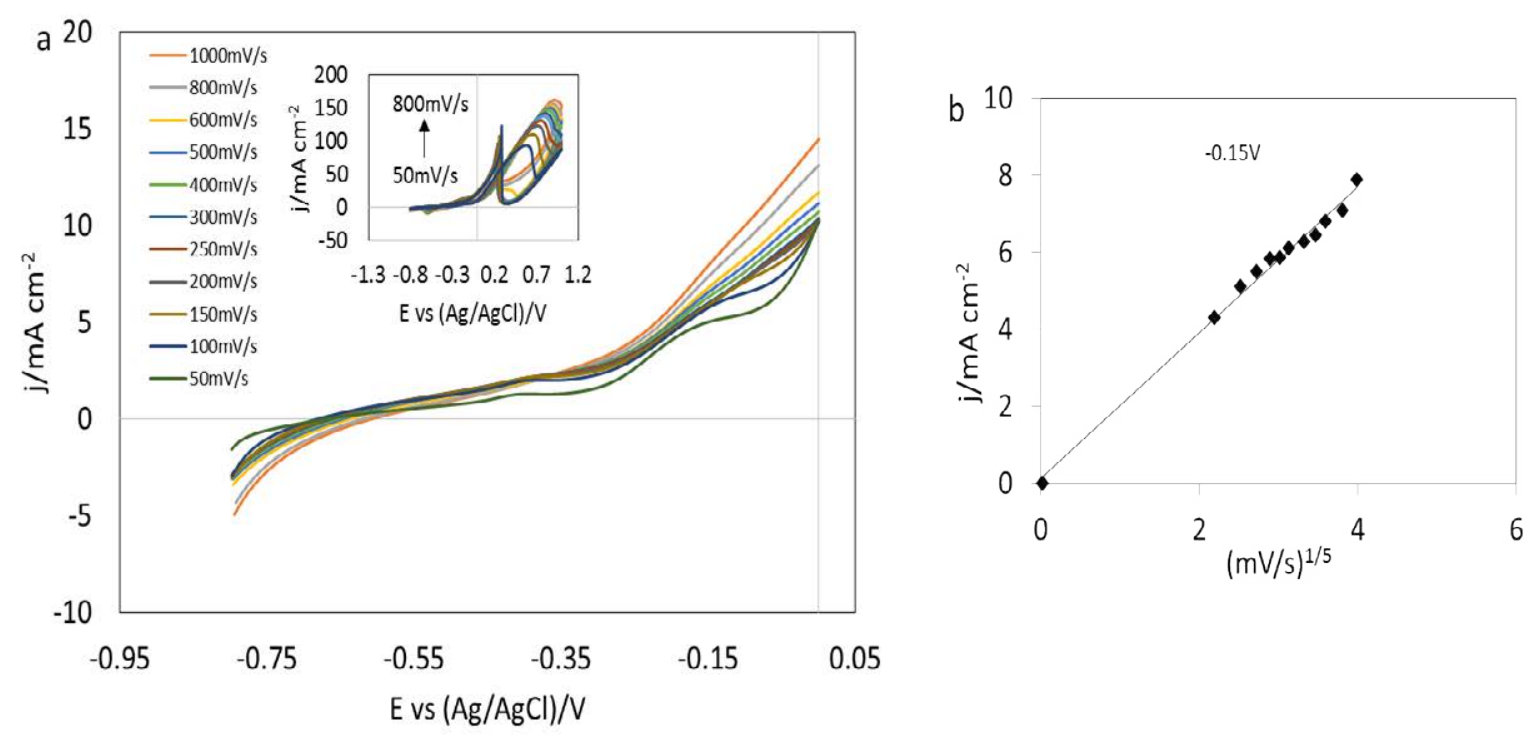

Figure 14 a) Scan rate effect on Cyclic Voltammetry of Cu-Au electrode b) Current density at $-0.15 \mathrm{~V}$ in relation with scan rate ( I vs. $\mathrm{v}^{1 / 5}$ ), on $1 \mathrm{M} \mathrm{C}_{3} \mathrm{H}_{8} \mathrm{O}_{3}+1 \mathrm{M} \mathrm{NaOH}$ electrolyte and $\mathrm{Ag}-\mathrm{AgCl}$ reference electrode.

Cu-Au shows a change in the voltammetry shape towards more negative potential. This may be explained by the electrochemical potential of copper and other copper ions in alkaline solution (copper oxide and copper hydroxide) which are more negative than gold in alkaline solution (Equation 3).

$\begin{array}{ll}\text { Reaction } & \mathrm{E}^{\circ} / \mathrm{V} \\ \mathrm{Au}^{2+}+\mathrm{e}^{-} \quad \mathrm{Au} & +1.8 \\ \mathrm{Cu}_{2} \mathrm{O}+\mathrm{H}_{2} \mathrm{O}+2 \mathrm{e}^{-} \quad \square \quad 2 \mathrm{Cu}+2 \mathrm{OH}^{-} & -0.360 \\ \mathrm{Cu}(\mathrm{OH})_{2}+2 \mathrm{e}^{-} \quad \mathrm{Cu}+2 \mathrm{OH}^{-} & -0.222\end{array}$

\section{Comparison of $\mathrm{Au}, \mathrm{Zn}-\mathrm{Au}$ and $\mathrm{Cu}-\mathrm{Au}$ electrode}

The behavior of $\mathrm{Au}, \mathrm{Zn}-\mathrm{Au}$, and $\mathrm{Cu}-\mathrm{Au}$ electrodes is compared in Figure 15a, the comparison has been done using the ideal plot for an anode material in a glycerol fuel cell (Figure 1), using the region between $-0.8 \mathrm{~V}$ and 0 in the cyclic voltammetry for glycerol oxidation in alkaline aqueous solution. Both $\mathrm{Zn}-\mathrm{Au}$ and $\mathrm{Cu}-\mathrm{Au}$ have similar behavior than the Au electrode in a solution of $1 \mathrm{M}$ glycerol and $1 \mathrm{M} \mathrm{NaOH}$ at $100 \mathrm{mV} / \mathrm{s}$ and $\mathrm{Ag} / \mathrm{AgCl}$ as a reference electrode. When analyzing the current densities at a potential of $-0.15 \mathrm{~V}$ (Figure 15b), the largest current density observed is from the $\mathrm{Zn}$-Au electrode with a value of $7 \mathrm{~mA} \mathrm{~cm}^{-2}$. The lowest current density observed is from the Au electrode with $0.7 \mathrm{~mA} \mathrm{~cm}^{-2}$ at a potential of $-0.45 \mathrm{~V}$. For all the electrodes studied the current density decreases while the potential goes to negative values. This behavior is lower in the $\mathrm{Zn}-\mathrm{Au}$ electrode and the $\mathrm{Cu}-\mathrm{Au}$ electrode when compare with the Au electrode. The experiment showed that changing the metal for gold deposition may have an effect on current density and potential and that $\mathrm{Zn}-\mathrm{Au}$ and $\mathrm{Cu}$-Au electrodes are possible materials to be used for glycerol oxidation in alkaline media.

Table 2 shows a list of different catalyst for glycerol oxidation compared with the catalyst used in our research. The experimental conditions show that different electrolyte compositions are used for the study of the glycerol oxidation. Furthermore, the comparison of the performance of the catalyst has not been studied in detail to our knowledge. E.g. the Pt, and Pd catalyst have different alkaline media $(\mathrm{NaOH}$ or $\mathrm{KOH})$, temperature and $\mathrm{pH}$. Nevertheless, in the analysis of different authors suggest that the glycerol oxidation is a complex reaction that is influenced by physical, chemical and electrochemical conditions and finding the right set of characteristics is still a challenge to research.

\section{Proof of concept: Chronoamperometry discharge analysis}

A prototype system was built to observe the discharge performance of the anode electrodes studied in this paper. Copper and zinc foils of $20 \mathrm{~cm}^{2}$ with electrodeposit gold were used as anodes for glycerol oxidation using the process described in Experimental Methods. The cathode was carbon graphite for the oxygen reduction reaction. The graphical representation of the cell is shown in Figure 16a. The two materials were immersed in a solution of $1 \mathrm{M}$ glycerol and $1 \mathrm{M} \mathrm{NaOH}$. Two different potentials were tested for 900 seconds in each cell $(-0.05 \mathrm{~V}$ and $-0.15 \mathrm{~V})$, the values were selected base in the results of EIS and CV analysis, taking into account the lowest resistance observed. The results are shown in Figure 16. Overall, it is observed that when the load potential is increased the current density decreases. In the case of the gold cell (Figure $\mathbf{1 6} \mathbf{b}$ ), at $-\mathbf{- 0 . 0 5} \mathrm{V}$ the current density average discharge is equal to $0.07 \mathrm{~mA} \mathrm{~cm}^{-2}$ and at $-0.15 \mathrm{~V}$ is equal to $0.01 \mathrm{~mA} \mathrm{~cm}^{-2}$. In the case of the $\mathrm{Zn}$-Au electrode (Figure 16c), the current density changes from $1.5 \mathrm{~mA} \mathrm{~cm}^{-2}$ (at $-0.05 \mathrm{~V}$ ) to 1 $\mathrm{mA} \mathrm{cm} \mathrm{c}^{-2}$ (at $-0.15 \mathrm{~V}$ ) and for the $\mathrm{Cu}$-Au electrode (Figure 16d) the current density average discharge is $3 \mathrm{~mA} \mathrm{~cm}^{-2}$ (at $-0.05 \mathrm{~V}$ ) and $1.5 \mathrm{~mA} \mathrm{~cm}^{-2}$ (at $-0.15 \mathrm{~V}$ ).

The difference between the cells current densities is possibly related to resistance that can be created between the electrodes. 

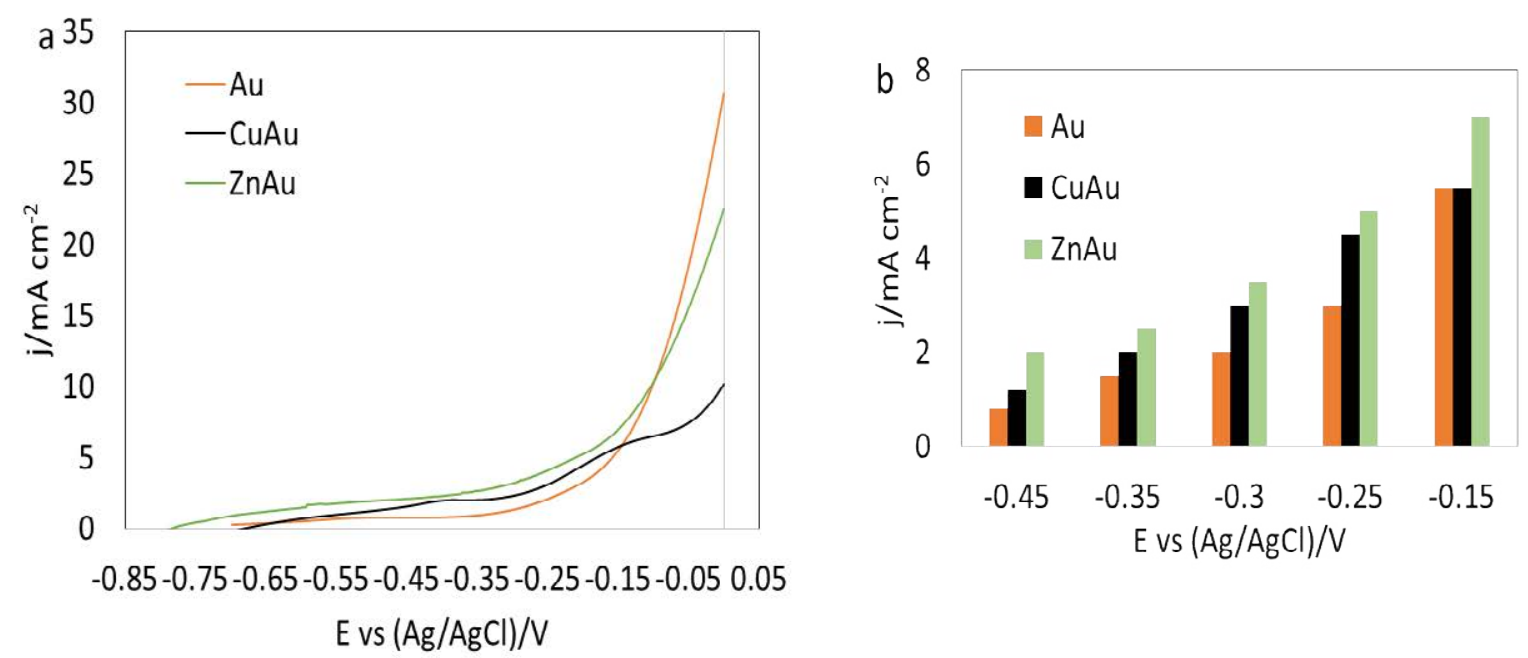

Figure 15 Cyclic voltammetry of $\mathrm{Au}, \mathrm{Zn}-\mathrm{Au}$, and $\mathrm{Cu}-\mathrm{Au}$ in $1 \mathrm{M} \mathrm{C}_{3} \mathrm{H}_{8} \mathrm{O}_{3}+1 \mathrm{M} \mathrm{NaOH}$ electrolyte, $100 \mathrm{mV} / \mathrm{s}$ and $\mathrm{Ag}-\mathrm{AgCl}$ reference electrode a) Zoom in voltammetry area between $-0.8 \mathrm{~V}$ to $0 \mathrm{~V}$ and b) Comparison of negative potentials with current density.

Table 2 Comparison of different catalyst for glycerol oxidation from literature with the present study.

\begin{tabular}{|c|c|c|c|c|c|}
\hline \multicolumn{6}{|c|}{ Experimental conditions } \\
\hline Catalyst & Supported material & Temperature $\mathrm{C}^{\circ}$ & pH & Main electrolyte & Observations \\
\hline Pt & $\begin{array}{c}\text { MCN (mesoporous carbon } \\
\text { nitrides) }{ }^{9}\end{array}$ & 60 & Neutral & $0.3 \mathrm{M}$ Glycerol & $\begin{array}{l}\text { There is a decrease of catalytic activity after } \\
\text { reusing of the catalyst also the experiments were } \\
\text { performed in a base free environment. }\end{array}$ \\
\hline \multirow[t]{2}{*}{ Pt-Ru } & $\begin{array}{l}\text { MWCNT (multi-walled } \\
\text { carbon nanotubes) }\end{array}$ & $20-90$ & Alkaline & $\begin{array}{l}0.7 \mathrm{M} \text { Glycerol+2M } \\
\mathrm{KOH}\end{array}$ & Superior catalytic activity than Pd -MWCNT \\
\hline & $\begin{array}{l}\text { MWCNT (multi-walled } \\
\text { carbon nanotubes) }{ }^{10}\end{array}$ & $20-90$ & Alkaline & $\begin{array}{l}0.7 \mathrm{M} \text { Glycerol+2M } \\
\mathrm{KOH}\end{array}$ & $\begin{array}{l}\text { It is observed higher current densities at } \\
\text { temperatures of } 80 \mathrm{Co}\end{array}$ \\
\hline $\mathrm{Pd}$ & $\begin{array}{l}\text { CCE (Carbon ceramic } \\
\text { electrode) }{ }^{11}\end{array}$ & 25 & Alkaline & $\begin{array}{c}0.5 \mathrm{~m} \mathrm{Glycerol}+0.3 \\
\mathrm{~m} \mathrm{NaOH}\end{array}$ & $\begin{array}{l}\text { The concentration of } \mathrm{NaOH} \text { influences the current } \\
\text { density of glycerol oxidation }\end{array}$ \\
\hline \multirow[t]{2}{*}{$\mathrm{Au}$} & Carbon $^{17}$ & $50-60$ & Alkaline & $\begin{array}{l}0.1 \mathrm{M} \text { Glycerol+0.1 } \\
\mathrm{NaOH}+0.1 \mathrm{M} \\
\text { Tartronic Acid }\end{array}$ & $\begin{array}{l}\text { The added tartronate improved the glycerol } \\
\text { oxidation due to selectivity of Au for tartronate } \\
\text { ions at high temperature }\end{array}$ \\
\hline & $\mathrm{MnO}_{2}$-Carbon ${ }^{22}$ & 60 & Alkaline & $\begin{array}{l}0.5 \mathrm{M} \text { Glycerol+1M } \\
\mathrm{KOH}\end{array}$ & $\begin{array}{l}\mathrm{MnO}_{2} \text { gave support for gold nanoparticles and } \\
\text { better electrode stability }\end{array}$ \\
\hline \multicolumn{6}{|c|}{ This Research } \\
\hline $\mathrm{Au}$ & $\begin{array}{l}\mathrm{Au} \\
\mathrm{GC} \\
\mathrm{Zn} \\
\mathrm{Cu}\end{array}$ & 23 & Alkaline & $\begin{array}{c}\text { 1M Glycerol + 1M } \\
\mathrm{NaOH}\end{array}$ & $\begin{array}{l}\text { High catalytic activity } \\
\text { Similar catalytic activity than gold } \\
\text { Higher current densities are observed and poten- } \\
\text { tially shifted to negative values } \\
\text { Higher current densities are observed and poten- } \\
\text { tially shifted to negative values }\end{array}$ \\
\hline
\end{tabular}

In the three cells tested gold was observed to have the lowest current output at the given potentials, followed by $\mathrm{Zn}-\mathrm{Au}$ and the highest current density was observed in the Cu-Au electrode. However, in the case of $\mathrm{Cu}-\mathrm{Au}$ at the end of the last discharge, it is observed a double line, indicating conductivity problems with the cell, this could be due to surface changes in the electrode after the discharge and possible surface oxidation $\left(\mathrm{Cu}_{2} \mathrm{O}\right.$ and/or $\left.\mathrm{Cu}(\mathrm{OH})_{2}\right)$. Further experimentation needs to be done in order to know the exact maximum capacity of the electrode and the gold bonding. Figure 16e shows the analysis of a three electrode fuel cell connected in series, the test was performed using different current densities in order to observe the discharge potential response and the stability of the cathode electrode for a period of $300 \mathrm{~s}$. While the current density increases the potential of the cell reduces constantly. At $0 \mathrm{~mA} \mathrm{~cm}{ }^{-2}$, the voltage of the cell is stable at $0.7 \mathrm{~V}$. However, the potential changes during the time when a load is not applied. This behavior suggests that the stability of the carbon electrode is changing during the $300 \mathrm{~s}$ experiment.

\section{Conclusions}

Our analysis shows that gold has the highest current density for glycerol oxidation in alkaline media when compared with another 

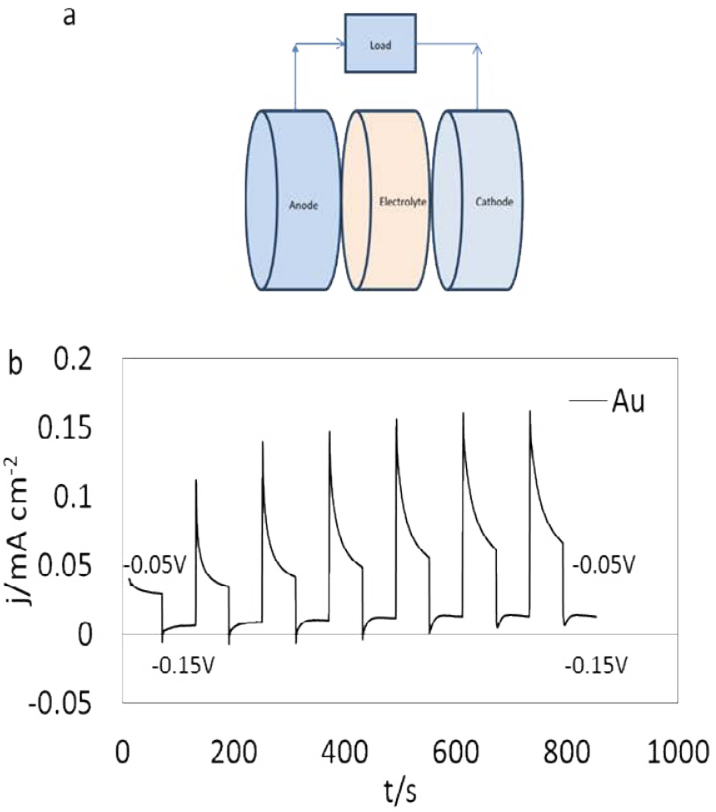
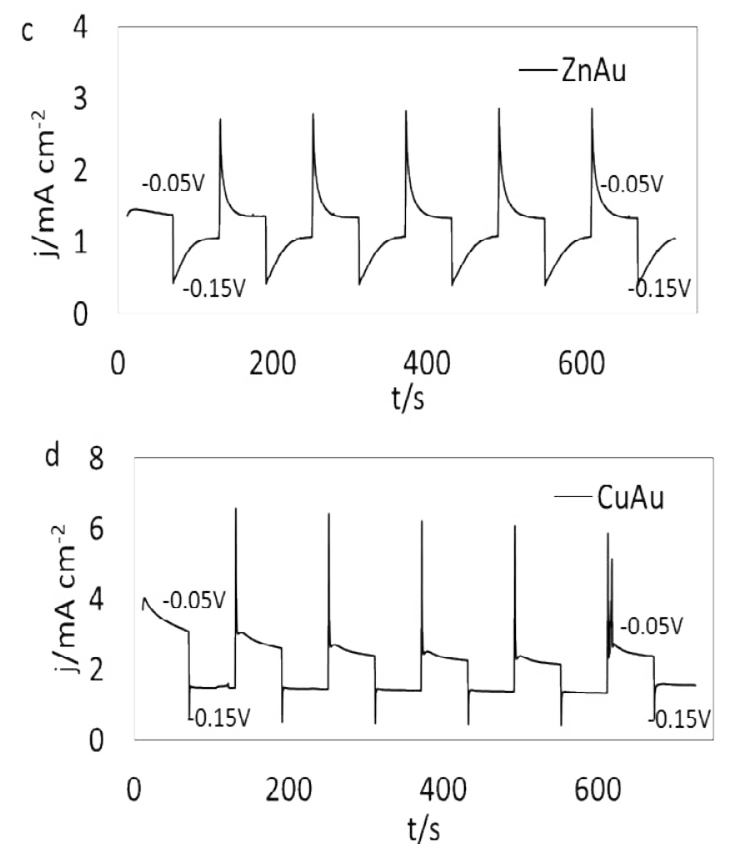

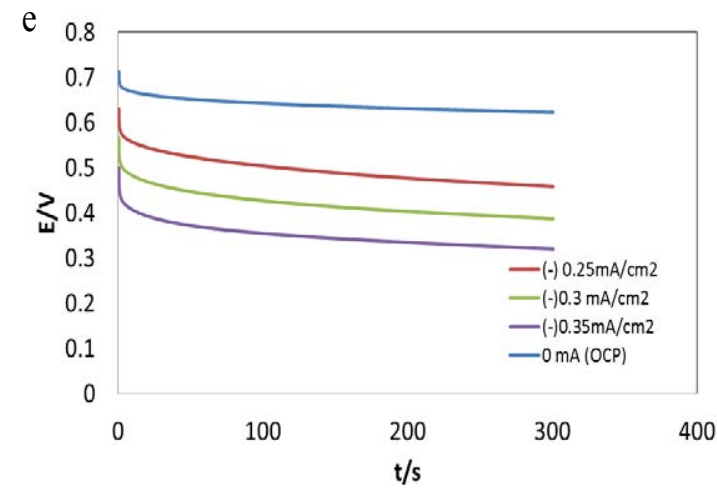

Figure 16

Discharge chronoamperometry at $-0.05 \mathrm{~V}$ and $-0.15 \mathrm{~V}$ using Carbon graphite as a cathode electrode, $\mathrm{C}_{3} \mathrm{H}_{8} \mathrm{O}_{3}+1$ $\mathrm{M} \mathrm{NaOH}$ electrolyte and a) representation of the fuel cell b) Au electrode c) Zn-Au electrode d) Cu-Au electrode and e) Discharge potential curve of a three series connected cells with carbon graphite as cathode electrode.

catalyst at a potential of $-0.2 \mathrm{~V}(\mathrm{Pt}, \mathrm{Ag}, \mathrm{GC}$ and $\mathrm{Cu})$. It is further observed that gold surface can change in cyclic voltammetry. The current density shows linear behavior with the scan rate at an exponential value of $1 / 5$ and not with the square root. One equivalent circuit fitted the data well at potentials of $-0.05 \mathrm{~V}$,$0.15 \mathrm{~V}$ and $-0.25 \mathrm{~V}$ vs. $\mathrm{Ag} / \mathrm{AgCl}$, with resistors and a Warburg element in parallel with the double layer capacitance. Elements are related to the possible presence of hydroxypyrovate and oxalate ions, our results were consistent with the low-frequency error fitting analysis $\left(10^{-4}\right)$, AC Simulink-Matlab fitting responds and the Kronig-Kramers transform test. The $\mathrm{Zn}-\mathrm{Au}$ and the $\mathrm{Cu}$ $\mathrm{Au}$ electrodes showed voltammetry behavior similar to the gold electrode in cyclic voltammetry at the different scan rate. The discharge chronoamperometry test showed that the $\mathrm{Zn}-\mathrm{Au}$ and $\mathrm{Cu}-\mathrm{Au}$ electrode had higher current densities than the gold electrode at a potential of $-0.25 \mathrm{~V}$ vs. $\mathrm{Ag} / \mathrm{AgCl}\left(5 \mathrm{~mA} \mathrm{~cm}{ }^{-2}, 4.5 \mathrm{~mA}\right.$ $18 \mathrm{~cm}^{-2}$, and $3 \mathrm{~mA} \mathrm{~cm}{ }^{-2}$ respectively). $\mathrm{Au}, \mathrm{Zn}-\mathrm{Au}$, and $\mathrm{Cu}-\mathrm{Au}$ are possible candidates for glycerol oxidation technologies and the gold coated metals are possibly suitable electrodes for building a fuel cell. In this study, the air electrodes used in the fuel cell test were limited instability and in our next study, we will address stable air electrodes for our glycerol fuel cell approach.

Upon success in prototyping, we aim to possibly use fuel cells as backup systems in microgrids or as an alternative to replace diesel generators in some situations. Although, more R\&D is needed to set this insight too. In the meanwhile, our group has started simulations with these propose glycerol fuel cell in order to anticipate on this scenarios.

\section{Acknowledgment}

This work was sponsored by the STW-I-Care 11854 project and $\mathrm{Dr}$ Ten BV, in The Netherlands as part of its ongoing fuel cell development research and demonstration of storage systems for smart grid integration. Also special thanks to MSc. Miheer Vaidya and the Delft University of Technology in The Netherlands. 


\section{References}

1 Ten KMV (1999) Anodic Oxidation of Formaldehyde on Gold Studied by Electrochemical Impedance Spectroscopy: An Equivalent Circuit Approach. J Electrochem Soc 146: 2146.

2 Perez KX, Baldea M, Edgar TF, Hoogsteen G, van Leeuwen RP, et al. (2016) Soft-islanding a group of houses through scheduling of CHP, PV and storage, in 2016 IEEE International Energy Conference (ENERGYCON) 1-6.

3 Hoogsteen G, Molderink A, Hurink JL, Smit GJM (2015) Managing energy in time and space in smart grids using TRIANA. IEEE PES Innov. Smart Grid Technol Conf Eu 2015-Janua 1-6.

4 Ciriminna R, Pina CD, Rossi M, Pagliaro M (2014) Understanding the glycerol market. Eur J Lipid Sci Technol 116: 1432-1439.

5 He Q, McNutt J, Yang J (2017) Utilization of the residual glycerol from biodiesel production for renewable energy generation. Renew Sustain Energy Rev 71: 63-76.

6 Ayoub M, Abdullah AZ (2012) Critical review on the current scenario and significance of crude glycerol resulting from biodiesel industry towards more sustainable renewable energy industry. Renew Sustain Energy Rev 16: 2671-2686.

7 Waidhas M, Drenckhahn W, Preidel W, Landes H (1996) Directfuelled fuel cells. J Power Sources 61: 91-97.

8 Liu W, Webb CJ, Gray EM (2016) Review of hydrogen storage in AB3 alloys targeting stationary fuel cell applications. Int J Hydrogen Energy 41: 3485-3507.

9 Granot E, Filanovsky B, Presman I, Kuras I, Patolsky F (2012) Hydrazine/air direct-liquid fuel cell based on nanostructured copper anodes. J Power Sources 204: 116-121.

10 Matos J, Borodzinski A, Zychora AM, Kedzierzawski P, Mierzwa B, et al. (2015) Direct formic acid fuel cells on Pd catalysts supported on hybrid TiO2-C materials. Appl Catal B Environ 163: 167-178.

11 Wang Z, Zhang B, Borthwick AGL, Feng C, Ni J (2015) Utilization of single-chamber microbial fuel cells as renewable power sources for electrochemical degradation of nitrogen-containing organic compounds. Chem Eng J 280: 99-105.

12 Wang FF, Shao S, Liu CL, Xu CL, Yang RZ, et al. (2015) Selective oxidation of glycerol over Pt supported on mesoporous carbon nitride in base-free aqueous solution. Chem Eng J 264: 336-343.

13 Falase A, Garcia K, Lau C, Atanassov P (2011) Electrochemical and in situ IR characterization of PtRu catalysts for complete oxidation of ethylene glycol and glycerol. Electrochem commun 13: 1488-1491.

14 Habibi E, Razmi H (2012) Glycerol electrooxidation on Pd, Pt and Au nanoparticles supported on carbon ceramic electrode in alkaline media. Int J Hydrogen Energy 37: 16800-16809.

15 Geraldes AN, Da Silva DF, E Silva LGDA, Spinacé EV, Neto AO, et al. (2015) Binary and ternary palladium based electrocatalysts for alkaline direct glycerol fuel cell. J Power Sources 293: 823-830.

16 Wang Z, Xin L, Zhao X, Qiu Y, Zhang Z, et al. (2014) Carbon supported Ag nanoparticles with different particle size as cathode catalysts for anion exchange membrane direct glycerol fuel cells. Renew Energy 62: 556-562.

17 Burke LD, Nugent PF (1997) The Electrochemistry of Gold: I The Redox Behaviour of the Metal. Gold Bull 30: 43-53.
18 Ureta-Zanartu MS, Berrios C, Gonzales T, Fernandez F, Baez D, et al. (2012) Electrocatalytic Oxidation of Alcohols at Gold Electrodes in Alkaline Media. Int J Electrochem Sci 7: 8905-8928.

19 Shi X, Simpson DE, Roy D (2015) The role of chemisorbed hydroxyl species in alkaline electrocatalysis of glycerol on gold. Phys Chem Chem Phys 17: 11432-11444.

20 Qi J, Xin L, Chadderdon DJ, Qiu Y, Jiang Y, et al. (2014) Electrocatalytic selective oxidation of glycerol to tartronate on $\mathrm{Au} / \mathrm{C}$ anode catalysts in anion exchange membrane fuel cells with electricity cogeneration. Appl Catal B Environ 154-155: 360-368.

21 Chornaja S, Kampars V, Zhizhkun S, Kulikova L (2013) Oxidation of glycerol with oxygen in alkaline aqueous solutions in the presence of supported palladium catalysts prepared by the extractive-pyrolytic method. React Kinet Mech Catal 108: 341-357.

22 Marshall AT, Golovko V, Padayachee D (2015) Electrochimica Acta Influence of gold nanoparticle loading in $\mathrm{Au} / \mathrm{C}$ on the activity towards electrocatalytic glycerol oxidation. Electrochim Acta 153: 370-378.

23 Kwon Y, Schouten KJP, Koper MTM (2011) Mechanism of the Catalytic Oxidation of Glycerol on Polycrystalline Gold and Platinum Electrodes. ChemCatChem 3: 1176-1185.

24 Kwon Y, Lai SCS, Rodriguez P, Koper MTM (2011) Electrocatalytic Oxidation of Alcohols on Gold in Alkaline Media. J Am Chem Soc 133: 6914-6917.

25 Padayachee D, Golovko V, Marshall AT (2013) The effect of $\mathrm{MnO}_{2}$ loading on the glycerol electrooxidation activity of $\mathrm{Au} / \mathrm{MnO}_{2} / \mathrm{C}$ catalysts. Electrochim Acta 98: 208-217.

26 Boukamp BA (2014) A Package for Impedance/Admittance Data Analysis. Solid State lonics 19: 1-5.

27 Boukamp BA (1986) A Nonlinear Least Squares Fit procedure for analysis of immittance data of electrochemical systems. Solid State lonics 20: 31-44.

28 Boukamp BA (2004) Electrochemical impedance spectroscopy in solid state ionics: Recent advances. Solid State Ionics 169: 65-73.

29 Boukamp BA (1995) A Linear Kronig-Kramers Transform Test for Immittance Data Validation. J Electrochem Soc 142: 1885-1894.

30 Dimitrijević S, Rajčić-Vujasinović M, Trujić V (2013) Non-cyanide electrolytes for gold plating-a review. Int J Electrochem Sci 8: 66206646.

31 Song X, Zhang D (2014) Bimetallic Ag-Ni/C particles as cathode catalyst in AFCs (alkaline fuel cells). Energy 70: 223-230.

32 Othman MR and Riyanto (2012) Electrochemical stability of $\mathrm{Cu}$, $\mathrm{Ni}, \mathrm{Co}, \mathrm{Pt}$ and Ir metals sheet and their composite electrodes in potassium hydrox de solution. Int. J. Electrochem. Sci 7: 8408-8419.

33 Chi-ucán SL, Castillo-atoche A, Borges PC, Manzanilla-cano JA, González-garcía G, et al. (2014) Inhibition Effect of Glycerol on the Corrosion of Copper in $\mathrm{NaCl}$ Solutions at Different $\mathrm{pH}$ Values. Corp J Chem 1-11.

34 Avramov-Ivić ML, Leger JM, Lamy C, Jović VD, Petrović SD (1991) The electro-oxidation of glycerol on the gold(100)-oriented single-crystal surface and poly crystalline surface in $0.1 \mathrm{M} \mathrm{NaOH}$. J Electroanal Chem 308: 309-317.

35 Singh PP (1977) A Model for lonic Behavior in Aqueous Solution. Activity Coefficients of Electrolytes at 298.15 K. J Am Chem Soc 99: 1312-1315. 
36 Sobri S, Roy S, Aranyi D, Nagy PM, Papp K, et al. (2008) Growth of electrodeposited gold on glassy carbon from a thiosulphate-sulphite electrolyte. Surf Interface Anal 40: 834-843.

37 Hezard T, Fajerwerg K, Evrard D, Collire V, Behra P, et al. (2012) Gold nanoparticles electrodeposited on glassy carbon using cyclic voltammetry: Application to $\mathrm{Hg}(\mathrm{II})$ trace analysis. J Electroanal Chem 664: 46-52.

38 Othman MR, Ahmad A (2015) Electrochemical oxidation of glycerol using gold electrode. Malaysian J Anal Sci 19: 291-299.
39 Vilchis-Carbajal S, González I, Lapidus GT (2000) Electrochemical study of gold cementation with zinc powder at low cyanide concentration in alkaline solutions. J Appl Electrochem 30: 217-229.

40 Okinaka Y, Kato M (2011) Electroless Deposition of Gold. In Modern Electroplating 483-498.

41 Guan YC and Han KN (1995) The Electrochemical Study of the Deposition of Gold onto Copper and Zinc in Ammoniacal Solutions. J Electrochem Soc 142: 1139-1143. 